\title{
Detection in the summer polar stratosphere of pollution plume from East Asia and North America by balloon-borne in situ CO measurements
}

\author{
G. Krysztofiak ${ }^{1}$, R. Thiéblemont ${ }^{1}$, N. Huret ${ }^{1}$, V. Catoire ${ }^{1}$, Y. Té ${ }^{2}$, F. Jégou ${ }^{1}$, P. F. Coheur ${ }^{4}$, C. Clerbaux ${ }^{3,4}$, S. Payan $^{2}$, \\ M. A. Drouin ${ }^{1}$, C. Robert ${ }^{1}$, P. Jeseck ${ }^{2}$, J.-L. Attié ${ }^{5,6}$, and C. Camy-Peyret ${ }^{2}$ \\ ${ }^{1}$ LPC2E, UMR7328, CNRS-Université d'Orléans, 3A Avenue de la Recherche Scientifique, \\ 45071 Orléans Cedex 2, France \\ ${ }^{2}$ LPMAA, UMR7092, UPMC Université Paris 06, CNRS, IPSL, 75005, Paris, France \\ ${ }^{3}$ UPMC Université Paris 06 \& Université Versailles St-Quentin; CNRS/INSU UMR8190, LATMOS-IPSL, \\ Paris, France \\ ${ }^{4}$ Spectroscopie de l'Atmosphère, Chimie Quantique et Photophysique, Université Libre de Bruxelles (ULB), \\ Brussels, Belgium \\ ${ }^{5}$ CNRM-GAME, Météo-France and CNRS, URA1357, Toulouse, France \\ ${ }^{6}$ Laboratoire d'Aérologie, UMR5560, Université de Toulouse and CNRS, Toulouse, France
}

Correspondence to: G. Krysztofiak (gisele.krysztofiak@cnrs-orleans.fr)

Received: 26 March 2012 - Published in Atmos. Chem. Phys. Discuss.: 18 June 2012

Revised: 5 November 2012 - Accepted: 16 November 2012 - Published: 17 December 2012

\begin{abstract}
The SPIRALE and SWIR balloon-borne instruments were launched in the Arctic polar region (near Kiruna, Sweden, $67.9^{\circ} \mathrm{N}-21.1^{\circ} \mathrm{E}$ ) during summer on 7 and $24 \mathrm{Au}-$ gust 2009 and on 14 August 2009, respectively. The SPIRALE instrument performed in situ measurements of several trace gases including $\mathrm{CO}$ and $\mathrm{O}_{3}$ at altitudes between 9 and $34 \mathrm{~km}$, with very high vertical resolution $(\sim 5 \mathrm{~m})$. The SWIR-balloon instrument measured total and partial column of several species including $\mathrm{CO}$. The $\mathrm{CO}$ stratospheric profile from SPIRALE for 7 August 2009 shows some specific structures with large concentrations in the low levels (potential temperatures between 320 and $380 \mathrm{~K}$, i.e. 10-14 km height). These structures are not present in the $\mathrm{CO}$ vertical profile of SPIRALE for 24 August 2009, for which the volume mixing ratios are typical from polar latitudes $(\sim 30 \mathrm{ppb})$. CO total columns retrieved from the IASI-MetOp satellite sounder for the three dates of flights are used to understand this $\mathrm{CO}$ variability. SPIRALE and SWIR CO partial columns between 9 and $34 \mathrm{~km}$ are compared, allowing us to confirm that the enhancement of $\mathrm{CO}$ is localised in the stratosphere. The measurements are also investigated in terms of $\mathrm{CO}: \mathrm{O}_{3}$ correlations and using several modelling approaches (trajectory
\end{abstract}

calculations, potential vorticity fields, results of chemistry transport model) in order to characterize the origin of the air masses sampled. The emission sources are qualified in terms of source type (fires, urban pollution) using $\mathrm{NH}_{3}$ and $\mathrm{CO}$ measurements from IASI-MetOp and fires detection from MODIS on board the TERRA/AQUA satellite. The results give strong evidence that the unusual abundance of $\mathrm{CO}$ on 7 August is due to surface pollution plumes from East Asia and North America transporting to the upper troposphere and then entering the lower stratosphere by isentropic advection. This study strengthens evidence that the composition of low polar stratosphere in summer may be affected by anthropogenic surface emissions through long-range transport.

\section{Introduction}

The polar stratosphere during summertime remains largely unexplored. Only few measurement campaigns such as POLARCAT (Jacob et al., 2010; Brock et al., 2011), POLARIS (Pierce et al., 1999), and SAMMOA (Orsolini, 2001) have been conducted, but they focussed more on spring and early 
summertime. In addition, the SPURT campaign (Engel et al., 2006; Hegglin et al., 2006) focussed on the transport in the UTC/LMS (upper troposphere/lowermost stratosphere) during the four seasons between 35 and $75^{\circ} \mathrm{N}$ over Europe.

Large scale transport and mixing between air masses from different latitude and altitude origins affect the distribution of trace gases and aerosols at polar latitudes, and can impact the stratospheric ozone budget. Ozone $\left(\mathrm{O}_{3}\right)$ change in the stratosphere affects the Earth radiative balance, which subsequently modifies the stratospheric circulation (Baldwin et al., 2007; Forster et al., 2005). It is consequently of the utmost importance to understand these effects. In the framework of the International Polar Year, the StraPolÉté project started on January 2009 (http://strapolete.cnrs-orleans.fr/). A successful balloon-borne campaign took place from Esrange near Kiruna $\left(67.9^{\circ} \mathrm{N}-21.1^{\circ} \mathrm{E}\right.$, Sweden) from 2 August to 12 September 2009 with eight balloon flights. One objective of the StraPolÉté project was to combine balloon measurements, satellite observations and modelling studies to characterize the dynamical state of the summer stratosphere in the polar region.

The polar atmosphere has been believed to be very clean for a long time. The polar atmosphere becomes, however, more and more polluted due to the increase of the pollutant emissions at northern mid-latitudes, followed by the longscale transport of the resulting pollution plumes (Raatz et al., 1984; Rinke et al., 2004). Carbon monoxide (CO) is one of these pollutants. Industrial processes, incomplete combustion, biomass burning and methane oxidation are the main sources of $\mathrm{CO}$ in the troposphere. At higher altitude in the stratosphere, $\mathrm{CO}$ is principally produced by methane oxidation. Reaction with $\mathrm{OH}$ is the main sink of $\mathrm{CO}$ in the troposphere and the lower stratosphere. $\mathrm{CO}$ has a chemical lifetime of around 2 months in the troposphere, allowing for possible direct transport into the stratosphere where its lifetime is much longer. $\mathrm{CO}$ is a good chemical tracer and, correlated with $\mathrm{O}_{3}$, is a powerful tool to study the exchange between troposphere and stratosphere (Fischer et al., 2000; Hoor et al., 2002; Brioude et al., 2006). CO plays an important role in the atmosphere oxidation capacity and in the production of tropospheric ozone. Ozone chemistry, enhanced in spring and summer, is closely depending on the $\mathrm{CO}$ and $\mathrm{NO}_{\mathrm{x}}$ emissions and on the season (Hegglin et al., 2006). Depending on the latitude, the typical tropospheric $\mathrm{CO}$ volume mixing ratios (vmr) can vary from 40 to $200 \mathrm{ppb}$ (Seinfeld and Pandis, 2006), with higher values in the Northern Hemisphere than in the Southern Hemisphere. The East Asia region is a large and increasing source of CO (Elliott et al., 1997; Akimoto et al., 2003). The intercontinental transport of $\mathrm{CO}$ pollution from that area can impact the troposphere and the stratosphere of different regions such as North America (Berntsen et al., 1999; Jaffe et al., 1999; Cooper et al., 2004) and Europe (Stohl et al., 2007; Fiedler et al., 2009). Indeed, East Asia is characterised by important transport from the boundary layer to the upper troposphere in air streams associated with mid-latitude cyclone called warm conveyor belt (WCB; Stohl et al., 2001; Liang et al., 2004). WCB is thought to be the primary mechanism for fast intercontinental transport of air plume pollution (Cooper et al., 2004). Stohl et al. (2007) and Liang et al. (2004) reported in particular the transport of polluted air masses across the central North Pacific atmosphere to North America, and then Europe via WCB.

Very recently, Roiger et al. (2011) reported case studies of trace gas export from East Asia, across the North Pole to Greenland's lowermost stratosphere $(11.3 \mathrm{~km}$ altitude $)$ via WCB. Most of the previous studies on the CO transport into the polar stratosphere used satellite measurements or airborne data (Harrigan et al., 2011; Roiger et al., 2011). In the present paper we analyse balloon-borne in situ measurements performed at high vertical resolution by the SPIRALE (French acronym for infrared absorption spectroscopy by embarked tunable laser diodes) instrument (Moreau et al., 2005). In particular we examine the situation on $7 \mathrm{Au}-$ gust 2009 , which was characterized by unusually large CO abundance in the lower stratosphere. These measurements from 7 August are compared to others performed during the campaign, on 24 August 2009 also by SPIRALE and on 14 August 2009 by the SWIR-balloon (Short Wave Infra Red Fourier transform spectrometer in nadir-looking) instrument (Té et al., 2002). In support of the in situ measurements we use IASI (Infrared Atmospheric Sounding Interferometer) CO satellite data (Clerbaux et al., 2009). As our analyses aim at understanding transport and source origin for the high-CO case, they rely as well on different modelling approaches. Finally, the possible CO sources (natural and/or anthropogenic) are qualified using $\mathrm{NH}_{3}$ measurements from IASI and fire detection from MODIS (MODerate resolution Imaging Spectroradiometer) instrument (Giglio et al., 2003) on Terra/Aqua satellites.

The instruments and models used to perform this study are described in Sect. 2. Section 3 presents the $\mathrm{CO}$ observations performed during the polar summer 2009 and their comparisons with satellite data. Using potential vorticity fields and trajectory calculations, we analyse the origin of the air masses sampled. Finally, in the discussion section we qualify the partitioning between tropospheric and stratospheric air using $\mathrm{CO}: \mathrm{O}_{3}$ correlation; we characterize the source types (fire/anthropogenic) and source locations (East Asia/North America) at the origin of the observed $\mathrm{CO}$ pollution.

\section{Instrument and model descriptions}

\subsection{Balloon-borne instruments}

Eight balloon-borne instruments were launched during the campaign between 2 August and 12 September 2009 from ESRANGE (Swedish Space Corporation) close to Kiruna $\left(67.9^{\circ} \mathrm{N}-21.1^{\circ} \mathrm{E}\right.$, Sweden). Among these flights, the SPIRALE instrument flew twice, once on 7 August (hereafter 
flight SPF07), and on another occasion on 24 August, (flight SPF24). The SWIR-balloon instrument flew on 14 August (flight SWF14).

SPIRALE is a spectrometer with six tunable laser diodes for in situ measurements of trace gas species from the upper troposphere to the middle stratosphere $(\sim 34 \mathrm{~km}$ height $)$. A detailed description of the instrument can be found in Moreau et al. (2005). In brief, the absorption of six laser beams in the mid-infrared region $(3-8 \mu \mathrm{m})$ takes place between two mirrors distant of $3.50 \mathrm{~m}$ in a multipass optical Herriott cell located at the extremities of a deployable mast below the gondola, leading to a path length of $430.5 \mathrm{~m}$. Several species, such as $\mathrm{O}_{3}, \mathrm{~N}_{2} \mathrm{O}, \mathrm{CH}_{4}, \mathrm{HCl}, \mathrm{NO}_{2}, \mathrm{HNO}_{3}$ and $\mathrm{CO}$, were measured with high frequency sampling $(\sim 1 \mathrm{~Hz})$, which leads to a vertical resolution of a few meters ( 3 to $5 \mathrm{~m}$ ), depending on the vertical velocity of the balloon. The overall uncertainties take into account the random and systematic errors, combined as the square root of their quadratic sum. The two main sources of random errors are the fluctuations of the laser background emission signal and the signal-tonoise ratio. At low altitudes $(<20 \mathrm{~km})$, these are the main contributions to overall uncertainties. Systematic errors originate essentially from the laser line width (an intrinsic characteristic of the laser diode), which contributes more at lower pressure than at higher pressure (lower altitude). For $\mathrm{CO}$, the overall uncertainty is on average $2.5 \%$ (with a standard deviation of $1.8 \%$ ) below $15 \mathrm{~km}$, increasing to $6 \%$ at $17 \mathrm{~km}$. For $\mathrm{O}_{3}$, the overall uncertainty significantly decreases from $50 \%$ at $13 \mathrm{~km}$, to $10 \%$ at $15 \mathrm{~km}$, and $4 \%$ at $17 \mathrm{~km}$. Absorption micro-windows for both flights were $2123.55-2123.80 \mathrm{~cm}^{-1}$ for carbon monoxide and $2123.40-2123.54 \mathrm{~cm}^{-1}$ for ozone. The following time sequences characterized the two SPIRALE flights:

- During SPF07, the first flight on 7 August 2009, the SPIRALE measurements started at 01:26 UTC, i.e. 03:26 local time. The balloon reached the maximum altitude of $34.2 \mathrm{~km}(7.28 \mathrm{hPa})$ at 03:20 UTC. The descent phase started at 03:32 UTC and the measurements ended at 06:00 UTC at $16.1 \mathrm{~km}(106.9 \mathrm{hPa})$.

- For SPF24, the second flight on the night of 24 to $25 \mathrm{Au}-$ gust 2009, the measurements started at 20:50 UTC and reached the maximum altitude of $34.1 \mathrm{~km}(6.9 \mathrm{hPa})$ at 22:30 UTC. The descent phase started at 23:26 UTCat $33.7 \mathrm{~km}$ and the measurements ended at 01:36 UTC at $16.7 \mathrm{~km}(94 \mathrm{hPa})$.

For both flights, retrievals of the species volume mixing ratios (vmr) were performed using ascent and descent phases. The study is focussed on the layer below $16 \mathrm{~km}$ altitude and thus only the ascent profiles allow studying this part of the atmosphere.

SWIR-balloon is an extended version in the short-wave infrared domain of the IASI-balloon instrument (Té et al., 2002). This instrument is an infrared remote sensing instru- ment based on a Fourier Transform interferometer. The interferometer is associated with two InSb detectors to cover both thermal infrared $(3-5 \mu \mathrm{m})$ and short-wave infrared (SWIR) (1.8-2.4 $\mu \mathrm{m})$ domains. The maximum optical path difference is fixed at $10 \mathrm{~cm}$. In nadir-looking, the SWIR-balloon observes the upwelling radiation which is composed of several contributions from the Earth surface emission, the emission and absorption of atmospheric constituents, the emission of the clouds and the reflected solar radiation. The recorded atmospheric spectra are radiometrically calibrated using two reference sources (Revercomb et al., 1988; Té et al., 2009). The LPMAA Atmospheric Retrieval Algorithm LARA (Clerbaux et al., 1999) is used to retrieve from the spectra total columns (from ground to $34 \mathrm{~km}$, the gondola height) of $\mathrm{CO}, \mathrm{O}_{3}, \mathrm{OCS}, \mathrm{CO}_{2}, \mathrm{~N}_{2} \mathrm{O}$ and $\mathrm{H}_{2} \mathrm{O}$. For the $\mathrm{CO}$ retrieval, the spectral window from 2149 to $2171 \mathrm{~cm}^{-1}$ was used. In addition to $\mathrm{CO}$, the contributions of the six atmospheric species $\mathrm{H}_{2} \mathrm{O}, \mathrm{O}_{3}, \mathrm{~N}_{2} \mathrm{O}$ (principal interferers) and $\mathrm{CO}_{2}, \mathrm{CH}_{4}$, and OCS has been taken into account. The SWIRballoon instrument was flown during the campaign on $14 \mathrm{Au}-$ gust 2009 at 09:26 UTC for $5 \mathrm{~h} 58 \mathrm{~min}$ and covered the distance from the position $\left(68.1^{\circ} \mathrm{N}, 21.0^{\circ} \mathrm{E}\right)$ for the first spectrum acquired at float to the last position $\left(68.4^{\circ} \mathrm{N}, 20.6^{\circ} \mathrm{E}\right)$ before the balloon cut-off. The altitude at float varied between 34.0 and $34.4 \mathrm{~km}$ according to the onboard GPS data.

\subsection{Satellite instruments}

Satellite data are used to enhance the interpretation of the balloon measurements. IASI on board MetOp satellite allows for interpreting the evolution of $\mathrm{CO}$ spatial distribution and MODIS (MODerate resolution Imaging Spectroradiometer) on TERRA/AQUA allows for locating the fires.

The polar-orbiting MetOp-A, launched on 19 October 2006, is the first of three successive MetOp satellites. The IASI-MetOp instrument is a nadir-looking high resolution Fourier transform spectrometer (FTS). It is designed to provide atmospheric temperature and water vapour profiles for operational meteorology. Atmospheric concentrations of several key species important to climate forcing and atmospheric chemistry monitoring can be derived from IASI radiance measurements (Clerbaux et al., 2009), including a variety of reactive compounds in fire or volcanic plumes (Clarisse et al., 2011). In addition, IASI-MetOp offers an excellent horizontal coverage due to its across-track swath width of $2200 \mathrm{~km}$, allowing for global coverage twice a day, with a field of view sampled by $2 \pm 2$ circular pixels each with a $12 \mathrm{~km}$ footprint diameter at nadir. IASI-MetOp measures $\mathrm{CO}$ on a global scale. CO total columns and vertical profiles (18 tropospheric layers and an additional upper layer) are retrieved in near real time from the nadir radiance spectra using the FORLI fast radiative transfer and retrieval software (George et al., 2009; Hurtmans et al., 2012). Here we also use $\mathrm{NH}_{3}$ total columns (Coheur et al., 2009) retrieved using a similar approach but restricted only to scenes 
where its spectral signature was unambiguously detected using a simple brightness temperature difference approach. Although this $\mathrm{NH}_{3}$ product has not yet been validated, it is worth stressing that the total columns are overall consistent with those retrieved locally using a full line-by-line radiative transfer model (Clarisse et al., 2010).

MODIS (Giglio et al., 2003) on NASA Terra (MOD14) and Aqua (MYD14) satellites detects a wide spectral range of electromagnetic energy spread in 36 spectral bands ranging from 0.405 to $14.385 \mu \mathrm{m}$. We use the fire and thermal anomalies from climate modelling grid fire products at $0.5^{\circ}$ resolution. Fire detection is performed using a contextual algorithm (Giglio et al., 2003) that exploits the strong emission of mid-infrared radiation from fires.

\subsection{Model}

Three models, namely FLEXTRA (Stohl et al., 1995), MIMOSA (Modèle Isentrope de transport Méso-échelle de l'Ozone Stratosphérique par Advection; Hauchecorne et al., 2002), and REPROBUS (REactive PRocesses ruling the Ozone BUdget in the Stratosphere; Lefèvre et al., 1994) have been used to calculate backward trajectories to track air mass origin, to calculate potential vorticity maps to study dynamical conditions, and to determine the $\mathrm{CO}$ emission regional distribution, respectively.

FLEXTRA is a Lagrangian atmospheric trajectory model, developed at the Institute of Meteorology and Geophysics University of Vienna to compute trajectories from meteorological fields of the European Centre of Medium-Range Weather Forecasts (ECMWF). We used the 3-hourly ERAInterim reanalysis fields (Dee et al., 2011) with a horizontal resolution of $1^{\circ} \pm 1^{\circ}$ and 60 vertical levels. Clusters of three-dimensional backward trajectories in a volume of size $0.5^{\circ} \pm 0.5^{\circ}$ along latitude and longitude and $500 \mathrm{~m}$ height have been performed.

Potential vorticity (PV) maps are calculated using the MIMOSA contour advection model. This model performs high resolution advection calculations based on the ERA-Interim reanalysis (Dee et al., 2011) of wind, pressure and temperature. MIMOSA initially computes the PV field at a resolution of $1.125^{\circ}$ in latitude and longitude vertically interpolated on an isentropic surface. This field is then interpolated on an $\mathrm{x}-\mathrm{y}$ grid centred on the North Pole with a horizontal resolution of $37 \pm 37 \mathrm{~km}$ (three grid points/degree) and advected with a time step of one hour. To preserve the homogeneity of the field, a regridding of the PV field on the original grid is calculated every $6 \mathrm{~h}$. The information on diabatic changes in the PV field at large scales can be extracted from the ERA-Interim fields. For the MIMOSA model this is done by applying to the advected field a relaxation towards the ERA-Interim PV field calculations with a time constant of 10 days. This technique allows running continuously MIMOSA over periods of several months in order to follow the evolution of dynamical barriers and fine scale structures such as vortex remnants and tropical intrusions (Marchand et al., 2003; Durry and Hauchecorne, 2005; Huret et al., 2006; Thiéblemont et al., 2011).

The REPROBUS 3D chemistry-transport model (Lefèvre et al., 1994; Jourdain et al., 2008) contains a detailed description of $\mathrm{O}_{\mathrm{x}}, \mathrm{NO}_{\mathrm{x}}, \mathrm{HO}_{\mathrm{x}}, \mathrm{ClO}_{\mathrm{x}}, \mathrm{BrO}_{\mathrm{x}}$ and $\mathrm{CHO}_{\mathrm{x}}$ chemistry. It calculates the chemical evolution of 55 species using 160 gas-phase reactions and 6 heterogeneous reactions. Reaction rates coefficients are taken from the recommendations of Sander et al. (2006). The photolysis rates are calculated at every time step using a look-up table from the Tropospheric and Ultraviolet Visible (TUV) model (Madronich et al., 1999). The REPROBUS model extends from the ground up to $0.1 \mathrm{hPa}$, with a vertical resolution varying from less than $1 \mathrm{~km}$ near the tropopause level to $2.2 \mathrm{~km}$ in the upper part of the stratosphere. The horizontal resolution used for this study is $2^{\circ} \pm 2^{\circ}$. Zonally symmetric initial tracer fields are taken from the two-dimensional model described by Bekki et al. (1993, 1994). To represent the CO variability over the Northern Hemisphere, a typical 2000s MOPITT CO climatological analysis (Claeyman et al., 2010) with $2^{\circ} \pm 2^{\circ}$ lat-lon resolution was used to fix the monthly $\mathrm{CO}$ source at $500 \mathrm{hPa}$ level. MOPITT CO data are referenced in numerous publications (see Deeter et al., 2003, 2010). Winds and temperatures (ERA-INTERIM) from ECMWF were used during the REPROBUS simulation to drive the transport of the stratospheric species and to compute their loss and production rates, respectively.

\section{Measurement description and interpretation}

One of the objectives of the StraPolÉté project was to study the origin of the polar stratospheric air in summer. This project combined both balloon-borne and satellite measurements with relevant dynamical models and chemistrytransport models.

\subsection{Variability of the tropopause altitude during August 2009}

The position of the tropopause plays a key role in the vertical distribution of the trace gas species (Hegglin et al., 2009). Indeed, the tropopause height provides a useful diagnosis to identify troposphere/stratosphere exchanges (Gettelman et al., 2011). Here, we used two definitions of the tropopause: the thermal tropopause $\left(T_{\mathrm{p}}\right)$ and the dynamical tropopause $\left(D_{\mathrm{p}}\right)$. The $T_{\mathrm{p}}$ is defined as the lowest level at which the lapse rates decrease to $2 \mathrm{~K} \mathrm{~km}^{-1}$ or less, and the lapse rates within the 2-km thick layer from this level do not exceed $2 \mathrm{~K} \mathrm{~km}^{-1}$ WMO (1957). The altitude of the $T_{\mathrm{p}}$ corresponds also to a vertical discontinuity in the static stability (Gettelman et al., 2011). The $D_{\mathrm{p}}$ is defined as the PV surfaces at $1.5,2$ and 3 PVU (Hoerling et al., 1991; Wernli et al., 2002; Gettelman et al., 2011), although the 2 PVU is generally used. 
Table 1. Comparisons of the CO partial columns between 9 and $34 \mathrm{~km}$ altitude between SPIRALE and SWIR balloon instruments during summer 2009.

\begin{tabular}{lllll}
\hline Date & & Instrument & $\begin{array}{l}\text { Column }(9-34 \mathrm{~km}) \\
(\text { molecules cm }\end{array}$ & $\begin{array}{l}\text { Errors } \\
(\text { molecules } \\
\left.\mathrm{cm}^{-2}\right)\end{array}$ \\
\hline $\begin{array}{l}7 \text { August } \\
\begin{array}{l}2009 \\
14 \text { August }\end{array}\end{array}$ & SPF07 & SPIRALE & $2.90 \times 10^{17}$ & \pm 0.06 \\
$\begin{array}{l}2009 \\
24 \text { August }\end{array}$ & SPF24 & SPIRALE & $1.58 \times 10^{17}$ & \pm 0.07 \\
2009 & & & & \pm 0.06 \\
\hline
\end{tabular}

During the StraPolÉté campaign, radio soundings (Vaisala Radiosonde RS92 type) were performed above Esrange to provide vertical profiles of ozone, pressure and temperature. Ozone profiles are shown in Fig. 1a. The red line denotes the $T_{\mathrm{p}}$ derived from temperature profiles. The $D_{\mathrm{p}}$ at 1.5, 2 and $3 \mathrm{PVU}$ (white contour) has been calculated from the ERA-Interim PV reanalyses. The tropopause altitude presents a large variability during August 2009, varying between $500 \mathrm{hPa}(\sim 6 \mathrm{~km})$ and $200 \mathrm{hPa}(\sim 12 \mathrm{~km})$ for the $D_{\mathrm{p}}$ and between $350 \mathrm{hPa}(\sim 8 \mathrm{~km})$ and $200 \mathrm{hPa}(\sim 12 \mathrm{~km})$ for the $T_{\mathrm{p}}$. The $D_{\mathrm{p}}$ for the three balloon flights was in the ranges $[11.5,11.9] \mathrm{km},[8.0,8.4] \mathrm{km}$ and $[5.7,8.7] \mathrm{km}$ for SPF07, SWF14 and SPF24, respectively, corresponding to $[1,3]$ PVU surfaces. The $T_{p}$ has also been calculated and was found to be 11.7, 9 and $9.5 \mathrm{~km}$ for SPF07, SWF14 and SPF24, respectively.

Generally, as seen in Fig. 1, the $D_{\mathrm{p}}$ and $T_{\mathrm{p}}$ are consistent, each other associated with the strong gradient observed in $\mathrm{O}_{3} \mathrm{vmr}([0.1,0.3] \mathrm{ppm})$ corresponding to the natural barrier created between the troposphere and the stratosphere. On 79, 20-21 and 29 August, the altitude of the tropopause is indeed higher than for the other days and the ozone gradient observed at the tropopause is weaker for these dates $(\sim 0.06$ $\mathrm{ppm} / \mathrm{km}$ for the three dates compared to $\sim 0.1 \mathrm{ppm} \mathrm{km}^{-1}$ for the other days). On 25 August, the $T_{\mathrm{p}}$ does not show a sharp decrease of the tropopause altitude as observed for the $D_{\mathrm{p}}$. The boundary between the troposphere and the stratosphere is often marked by a band of strong PV gradient (Holton et al., 1995) observed during all August 2009, except on $25 \mathrm{Au}-$ gust 2009 where the transition is more extended. Moreover, a high ozone vmr $([0.1,0.35] \mathrm{ppm})$ is observed below the $T_{\mathrm{p}}$ on 25-26 August typical of stratospheric ozone values. These results suggest that an intrusion of stratospheric air deep into the troposphere occurred on 25 August.

SPF07 and the SPF24 flights were thus conducted during specific dynamical events. Figure $1 \mathrm{~b}$ represents the ozone vertical profile from SPIRALE instrument during SPF07 and SPF24. During these flights, the Vaisala Radiosondes were flown as piggy back on the SPIRALE instrument and the ozone profiles resulting are also shown in Fig. 1b. We can notice that the SPIRALE and Vaisala profiles are in accor-
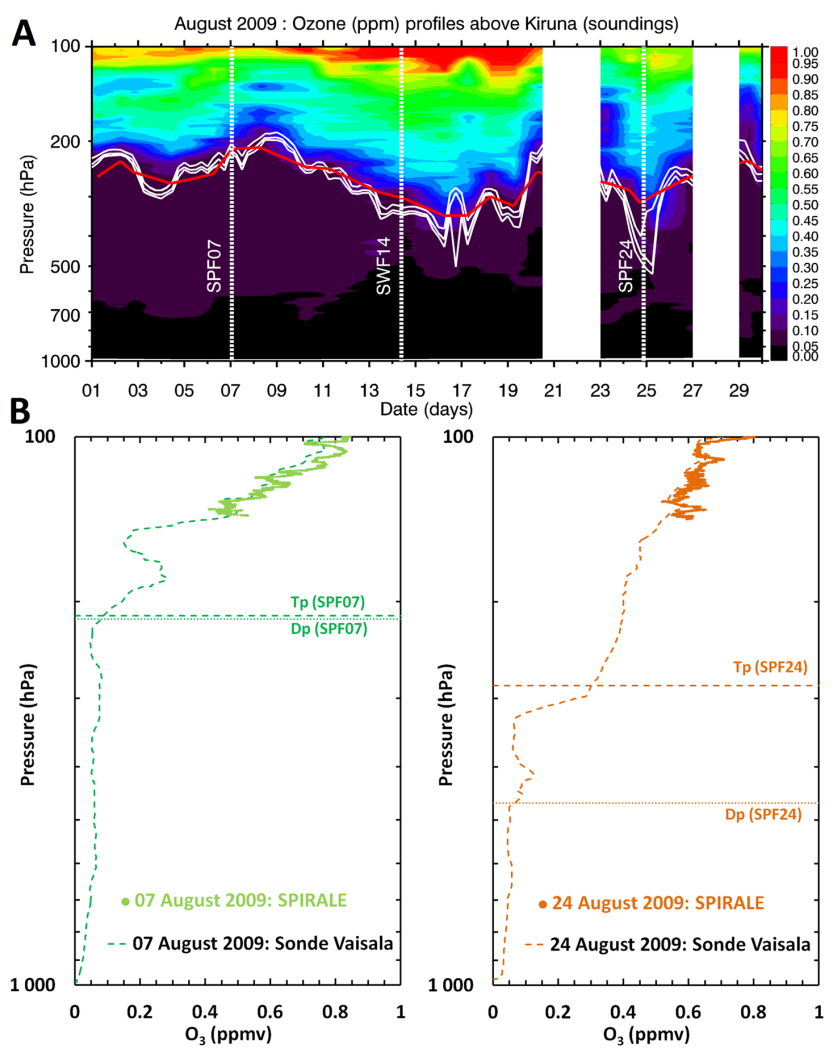

Fig. 1. (A) Ozone volume mixing ratio (vmr) in ppm over Kiruna from soundings (Vaisala Radiosonde RS92 type, www. vaisala.com) during August 2009 with the three flights SPF07, SWF14 and SPF24 represented in dashed lines. The white lines correspond to the $1.5,2$ and 3 PVU potential vorticity contours (1 PVU $=10^{-6} \mathrm{~K} \mathrm{~m}^{2} \mathrm{~kg}^{-1} \mathrm{~s}^{-1}$ ) from ECMWF era-interim data corresponding to the dynamical tropopause. The red line corresponds to the thermal tropopause. (B) Ozone vmr in ppm from SPIRALE (coloured dots) and from Vaisala sounding (dash line) on 7 August 2009 (SPF07: green) and on 24 August 2009 (SPF24: orange). The $T_{\mathrm{p}}$ (dashed lines) and $D_{\mathrm{p}}$ (at $2 \mathrm{PVU}$ ) (dot line) are represented for each flight.

dance and are well connected. The tropopause altitudes are represented by dashed line for the $T_{\mathrm{p}}$ and by dotted line for the $D_{\mathrm{p}}$ (at $2 \mathrm{PVU}$ ). An ozone gradient at the tropopause is observed for the SPF07 and just below the $T_{\mathrm{p}}$ for the SPF24. The SPF07 sounding corresponds to a situation with a high tropopause and low ozone values are observed above the tropopause. SPF24 is characterized by a low $D_{\mathrm{p}}$ altitude (from 300 to $500 \mathrm{hPa}$ ) and an increase of ozone values above the $D_{\mathrm{p}}$ (a phenomenon more marked in the radiosounding 6 hours later), typical for a stratospheric intrusion case.

In the following, we choose the $T_{\mathrm{p}}$ as reference for the tropopause so as to rely on SPIRALE measurements of temperature, pressure and trace gas. 


\subsection{CO column variability during August 2009}

The CO total columns from IASI-MetOp are shown in Fig. 2, represented in coloured squares for all overpasses around the Kiruna region for the three flights (SPF07, SWF14 and SPF24). The locations of the SPIRALE instrument trajectories are shown in black (top and bottom panels), and the SWIR data are shown in coloured circles (middle plot). When comparing the three figures, it appears that IASI CO total columns are different for each date:

- On 7 August a mean CO total column of $(1.88 \pm 0.12) \pm 10^{18}$ molecules $\mathrm{cm}^{-2}$ is observed by IASI-MetOp close to the SPF07 flight track and in the entire range of latitude-longitude presented.

- On 14 August, the IASI-MetOp CO total columns are comparable to the $\mathrm{CO}$ total column measurements of SWF14 (coloured circle). Indeed, the mean CO total column from IASI is $(1.55 \pm 0.10) \pm 10^{18}$ molecules $\mathrm{cm}^{-2}$, whereas the average column retrieved from the SWIR-balloon is $(1.64 \pm 0.08) \pm 10^{18}$ molecules $\mathrm{cm}^{-2}$ at the location of $68.2^{\circ} \mathrm{N}-20.7^{\circ} \mathrm{E}$. The spatial and temporal co-location is less than $0.5^{\circ}$ in latitude and in longitude for the closest overpass as compared to the SWF14 trajectory.

- On the night of 24 to 25 August during SPF24, the IASI CO total columns reveal some high values in the east region, similar to those obtained on 7 August (Fig. 2a). However, in the vicinity of the SPF24 flight track, CO total columns are below $(1.69 \pm 0.09) \pm 10^{18}$ molecules $\mathrm{cm}^{-2}$.

The $\mathrm{CO}$ total column measured on 7 August is thus on average $15 \%$ higher than the $\mathrm{CO}$ total columns on 14 August and on 24 August (close to the SPF24 flight track).

In order to derive information on the altitude range (stratosphere/troposphere) corresponding to the high $\mathrm{CO}$ total column values measured by IASI, we have calculated the $\mathrm{CO}$ partial columns from 9 to $34 \mathrm{~km}$ height (Table 1) measured by SPIRALE and SWIR-balloon instruments for the three balloon flights. It appears that whereas SWF14 and SPF24 partial columns are of the same order of magnitude, SPF07 partial column is around two times larger.

To conclude, the difference in the total column values between 7 August and 14 and 24 August is on average $0.2 \times 10^{18}$ molecules $\mathrm{cm}^{-2}$ and the difference in the partial columns (between 9 and $34 \mathrm{~km}$ ) is about $0.15 \times 10^{18}$ molecules $\mathrm{cm}^{-2}$. Consequently, the increase in the total column values is mainly (around $75 \%$ ), explained by the change in the $\mathrm{CO}$ concentration in the altitude range $[9,34] \mathrm{km}$. In the following, we focus on this part of the atmosphere.

\subsection{Vertical distribution of $\mathrm{CO}$ from in situ measurements}

The CO vertical profiles for both SPIRALE flights are displayed in Fig. 3 with altitude relative to the $T_{\mathrm{p}}$.

The SPF24 vertical profile presents a $30-35$ ppb averaged volume mixing ratio (vmr) above the $T_{\mathrm{p}}$. In this profile part a very slight decrease of $\mathrm{CO} \mathrm{vmr}$ with increasing altitude is observed. A CO gradient just at the $T_{\mathrm{p}}$ and an increase in $\mathrm{CO}$ values with decreasing altitudes below the $T_{\mathrm{p}}$ are observed. On the contrary, during SPF07, the CO profile presents strong variations and the $\mathrm{vmr}$ is greater by up to $60 \mathrm{ppb}$ as compared to the SPF24 vmr. The SPF07 profile is in fact mainly characterized by two layers, one (L1) between 10.7 and $12.6 \mathrm{~km}\left(1.0 \mathrm{~km}\right.$ below the $T_{\mathrm{p}}$ and $0.9 \mathrm{~km}$ above the $T_{\mathrm{p}}$ ) with $\sim 70-80 \mathrm{ppb} \mathrm{CO}$, so located in the upper troposphere and lower stratosphere, and the other one (L2) between $12.6 \mathrm{~km}$ altitude $\left(0.9 \mathrm{~km}\right.$ above the $\left.T_{\mathrm{p}}\right)$ and $14.1 \mathrm{~km}\left(2.4 \mathrm{~km}\right.$ above the $\left.T_{\mathrm{p}}\right)$ with $\sim 35-45 \mathrm{ppb}$ CO located in the stratosphere. In each layer, many thin structures are observed as evidences of atmospheric fine scale disturbance. At the height of $2.4 \mathrm{~km}$ above the $T_{\mathrm{p}}$, both vertical profiles show similar features with $\mathrm{CO} v \mathrm{vmr}$ around $30 \mathrm{ppb}$, decreasing smoothly with altitude.

\subsection{Data interpretation}

\subsubsection{Dynamical conditions}

The stratospheric dynamical conditions are examined using the MIMOSA model results for 7, 14 and 24 August 2009 (Fig. 4):

- On 7 August during SPF07 (Fig. 4, top panels), a large low latitude air mass tongue ( $\mathrm{PV}<6 \mathrm{PVU}$ ) is located above Northern Europe at $340 \mathrm{~K}$ isentropic level (i.e. $12 \mathrm{~km}, \mathrm{~L} 1$ ). At $380 \mathrm{~K}$ (i.e. $14 \mathrm{~km}, \mathrm{~L} 2$ ), a thinner low latitude intrusion is recorded. The SPF07 vertical profile, recording two high $\mathrm{CO}$ laminae represented by $\mathrm{L} 1$ and L2 in Fig. 3, is in agreement with the MIMOSA maps where low PV intrusions are detected;

- On 14 August, high PV values (> 10 PVU) are observed above Kiruna (denoted by the white cross) at 340 and $380 \mathrm{~K}$ (Fig. 4, mid panel). This suggests the presence of typical polar air during the SWF14, which is confirmed by examining the SWIR results (Fig. 2b) having CO total column values typical from polar latitude;

- On 24 August finally, MIMOSA results at $340 \mathrm{~K}$ show that the launch of SPF24 occurred into a thin filament of high PV value located between two tongues of low PV (lower latitude). Such fine scale dynamical features are less pronounced at $380 \mathrm{~K}$. The SPF 24 vertical profile (Fig. 3, orange) and IASI CO total column (Fig. 2c, in the south-west part) display that low $\mathrm{CO}$ values have 

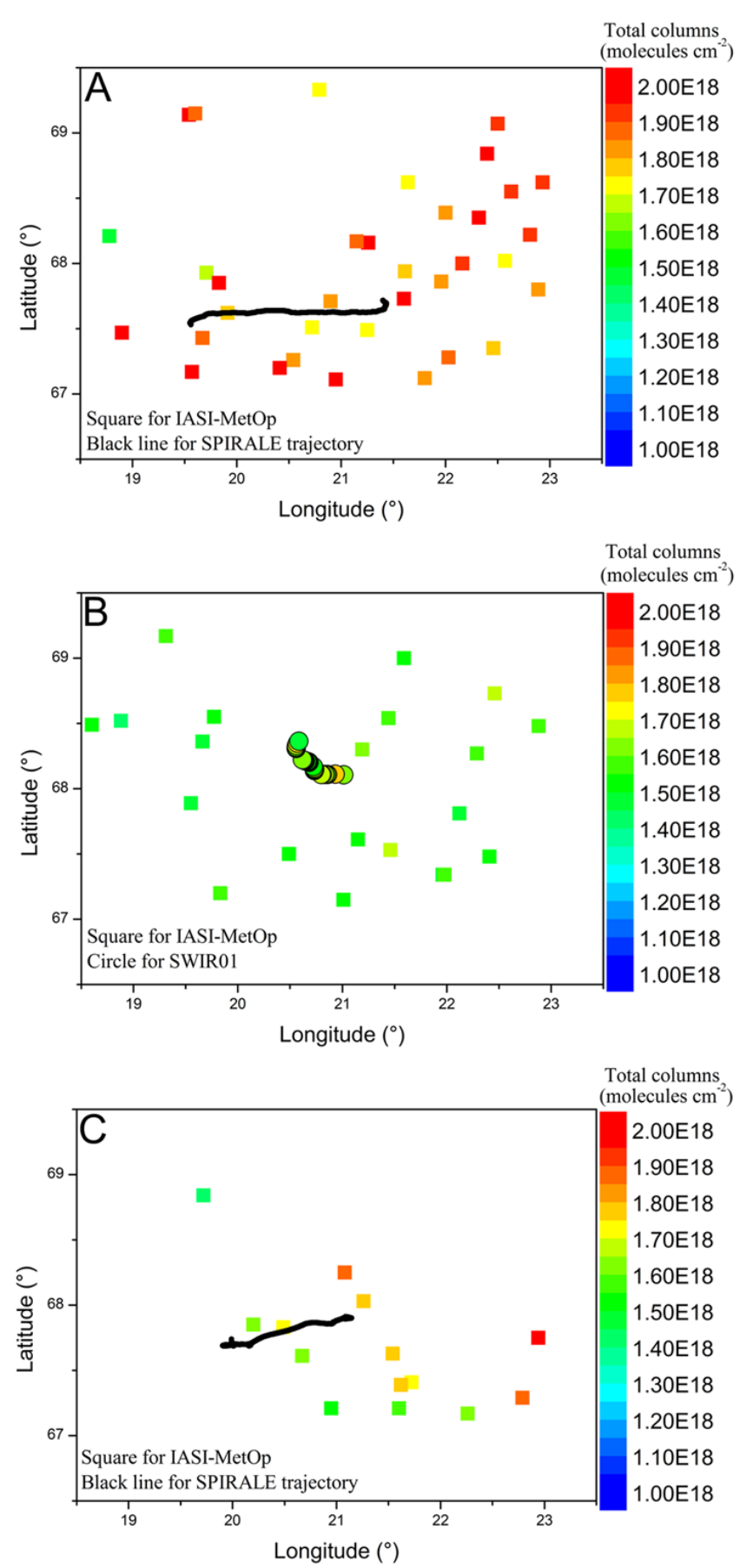

Fig. 2. Maps of CO total columns (molecules $\mathrm{cm}^{-2}$ ) from IASIMetOp satellite data, (A) on 7 August 2009, (B) on 14 August 2009 and (C) on 24 August 2009. IASI CO data are compared with balloon-borne data from SWIR01 instrument (coloured circles) on 14 August 2009, and the locations of the SPIRALE instrument trajectories are represented by the black solid line in (A) and (C).

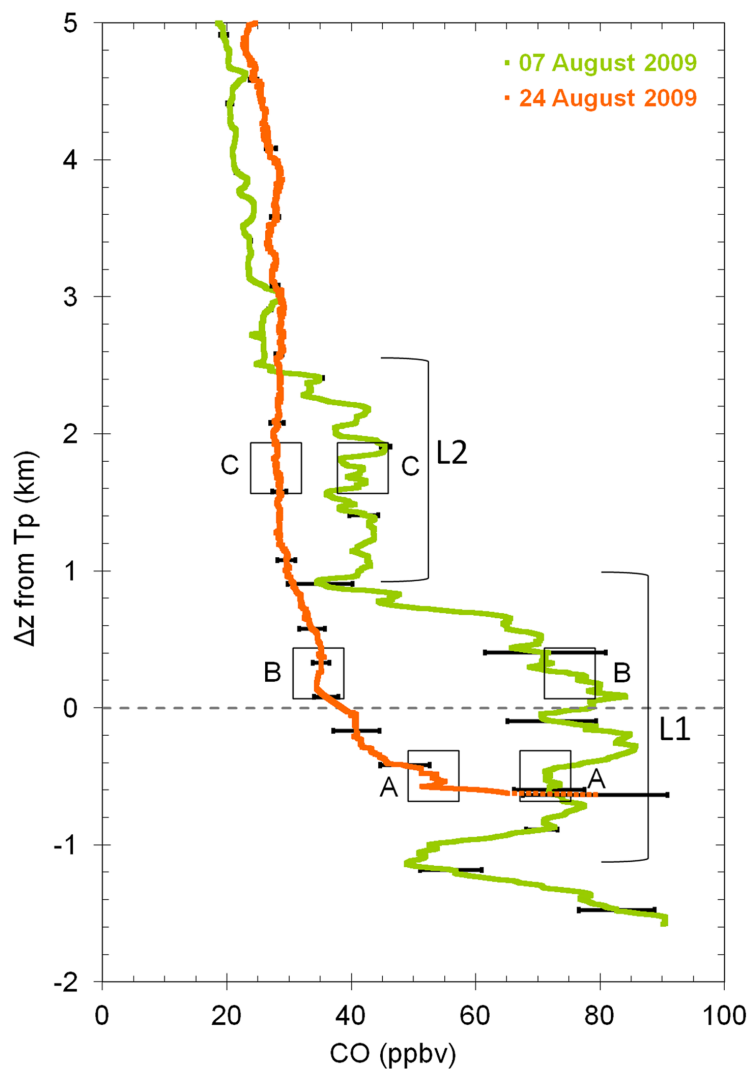

Fig. 3. SPIRALE vertical profiles of $\mathrm{CO}$ volume mixing ratios (in ppb) with error bars above Esrange $\left(67.9^{\circ} \mathrm{N}-21.1^{\circ} \mathrm{E}\right.$, Sweden) on 7 August (green) and 24 August 2009 (orange). The vertical axis is the altitude relative to the thermal tropopause $\left(T_{\mathrm{p}}\right)$. The squares labelled $\mathrm{A}, \mathrm{B}$ and $\mathrm{C}$ represent the altitudes of the clusters for the backward trajectories. L1 and L2 indicate two different layers (see Sect. 3.3).

been recorded, which is in agreement with the PV maps where polar air is detected along the flight position.

In summary, balloon measurements and MIMOSA maps are consistent with each other at the same isentropic levels. In particular, the MIMOSA model allows reproducing very thin dynamical structures such as polar filaments and low latitudes intrusions. However, the MIMOSA PV diagnosis does not inform on the origin of the 7 August high CO laminae. This aspect is investigated using the FLEXTRA trajectory calculation model.

\subsubsection{Trajectory calculations}

To investigate the origin of the polluted air masses sampled during SPF07 compared to the air sampled during SPF24, we have calculated 10-day 3-D backward trajectories (Fig. 5) for the three clusters corresponding to the top and bottom of L1 layer (squares A and B in Fig. 3) and to the middle of the L2 layer (square $\mathrm{C}$ in Fig. 3). The backward trajectories A and B are calculated each side of the thermal tropopause. In Fig. 5, 

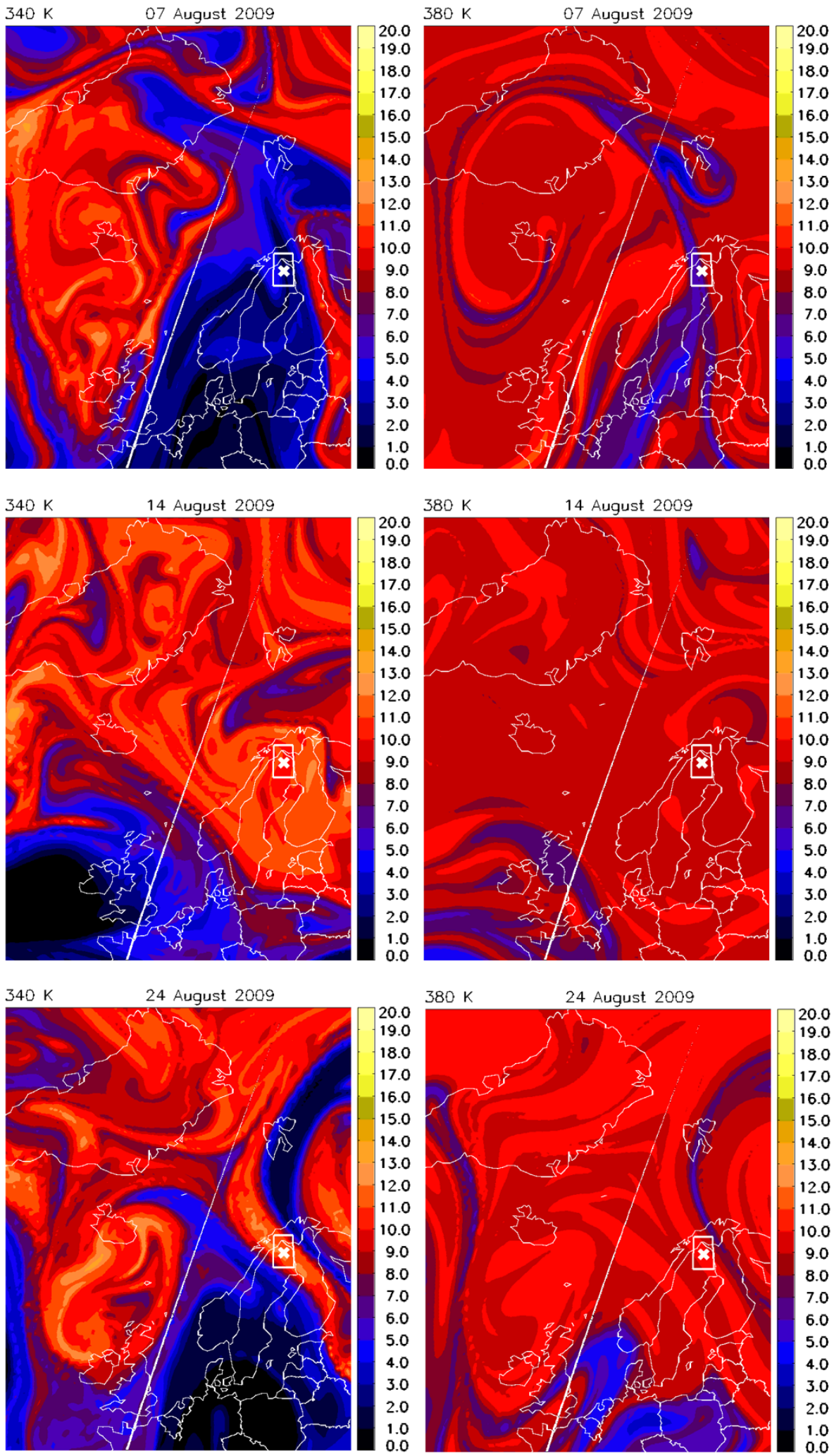

Fig. 4. Potential vorticity ( $1 \mathrm{PVU}=10^{-6} \mathrm{~K} \mathrm{~m}^{2} \mathrm{~kg}^{-1} \mathrm{~s}^{-1}$ ) from MIMOSA model at the $340 \mathrm{~K}$ level (left panels) and $380 \mathrm{~K}$ level (right panels) on 7 August 2009 at 00:00 UTC (top panels), on 14 August 2009 at 12:00 UTC (middle panels) and on 24 August 2009 at 18:00 UTC (bottom panels). The white cross shows the location of the balloon flights and the white square shows the position of the latitude-longitude shown in Fig. 2. 

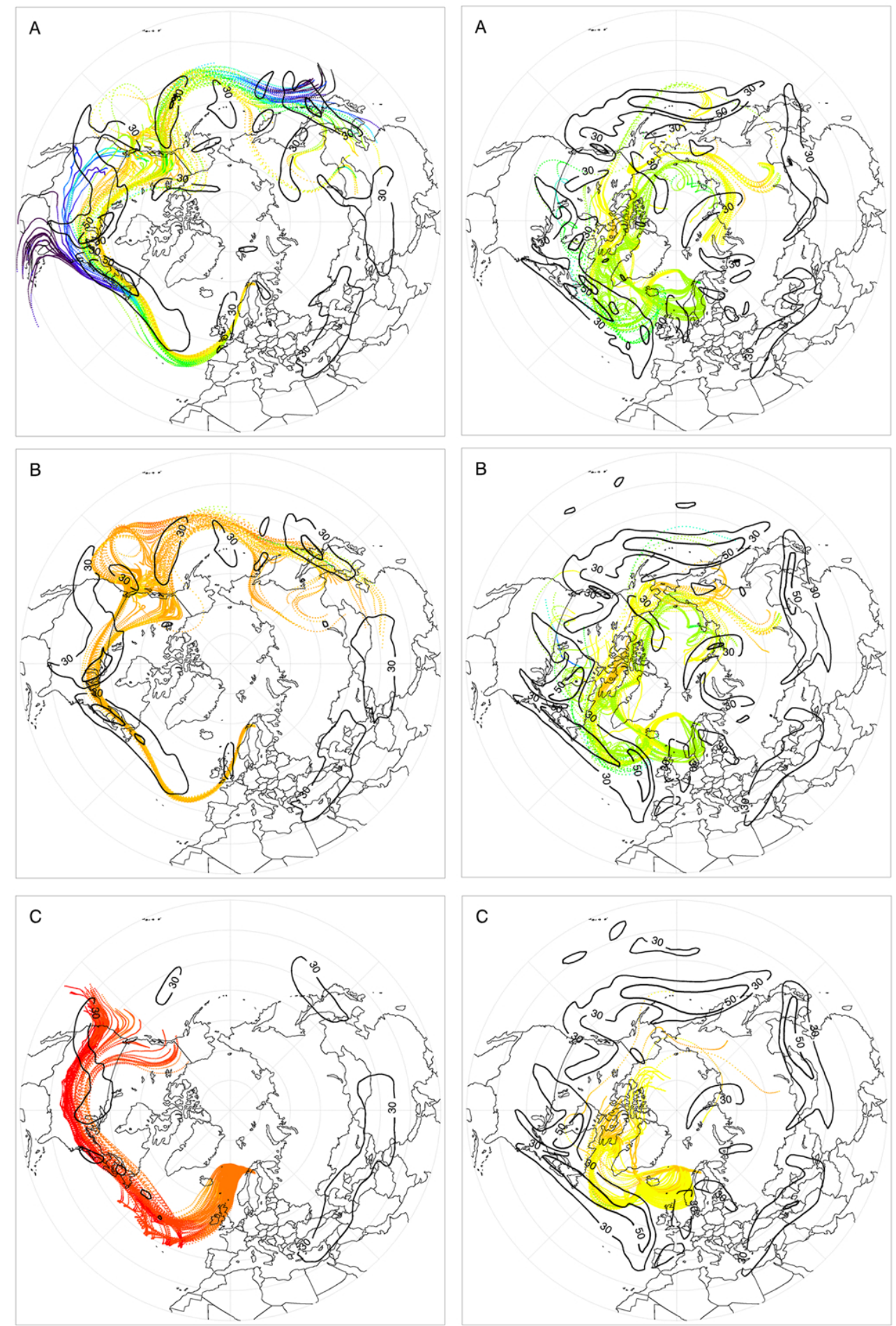

$\begin{array}{llllllllllllllllll}0.0 & 1.0 & 2.0 & 3.0 & 4.0 & 5.0 & 6.0 & 7.0 & 8.0 & 9.0 & 10.0 & 11.0 & 12.0 & 13.0 & 14.0 & 15.0 & 16.0\end{array}$

Altitude (km)

Fig. 5. Ten days backward trajectories calculated by the FLEXTRA model (Stohl et al., 1995) on 7 August 2009 (left panels) and on 24 August (right panels) for clusters centred in altitude relative to the thermal tropopause at (A) $-500 \mathrm{~m},(\mathbf{B})+250 \mathrm{~m},(\mathbf{C})+1750 \mathrm{~m}$, coupled with the ERA-Interim horizontal wind module on 7 August 2009 (black solid line) $\left(\mathrm{m} \mathrm{s}^{-1}\right.$ ) at (A) $225 \mathrm{hPa},(\mathbf{B}) 200 \mathrm{hPa}$ and (C) $150 \mathrm{hPa}$ and on 24 August 2009 at (A) $300 \mathrm{hPa},(\mathbf{B}) 250 \mathrm{hPa}$ and (C) $225 \mathrm{hPa}$. 
we superimposed the horizontal wind speed $\left(30 \mathrm{~m} \mathrm{~s}^{-1}\right.$ and $50 \mathrm{~m} \mathrm{~s}^{-1}$ black isocontours) to indicate the location of the jet stream. The altitude of the air masses along the trajectories is illustrated by the colour code:

- For the SPF07 (Fig. 5, left column), the trajectories of panel A (L1 bottom, Fig. 3) show that high vertical transport occurred above North America and East Asia, allowing several air masses to be lifted from the ground to $10 \mathrm{~km}$ altitude in a few days. Following this ascent, the trajectories are advected eastward by the upper tropospheric jet stream. Panel B shows that the altitude along the trajectories is in the range $[10,14] \mathrm{km}$, thus that the transport is essentially horizontal and consistent with the location of the jet stream. On panel C (L2, Fig. 3), the influence of the jet stream on the horizontal transport still remains present although it starts to decrease at these altitudes $(\sim 13.5 \mathrm{~km})$. The air masses sampled in the L2 are associated with an intrusion of air from North America $\left(30-45^{\circ} \mathrm{N},\left(-75^{\circ}\right)-\left(-120^{\circ}\right) \mathrm{E}\right)$ into polar stratosphere via isentropic transport along the 340-380 K level.

- The trajectories corresponding to the SPF24 (Fig. 5, right column) show that during their 10 days transport, air masses were advected from northern Asia (panels A and B) and North America (panel C) and northward of the jet stream (latitude $>60^{\circ} \mathrm{N}$ ). The altitude evolution on the A and B panels reveals that air masses undergo a descent of $\sim 2 \mathrm{~km}$ from North America to Kiruna ([10, $11] \mathrm{km}$ to $[8,9] \mathrm{km}$ and $[10,12] \mathrm{km}$ to $[9,10] \mathrm{km}$, respectively). These altitude decreases along the trajectories are consistent with the event of stratospheric intrusion previously reported (Fig. 1, Sect. 3.1). The trajectories of the $\mathrm{C}$ panel do not reveal a significant fluctuation of the altitude.

The transport analysis confirms that SPF07 has sampled very different air masses in the polar region as compared to the other flights. This resulted in various long-range transport regimes: in the upper troposphere, fast transport from the mid-latitude ground (North America and East Asia) to the free troposphere occurred, followed by isentropic transport (for L1), whereas in the lowermost stratosphere, isentropic transport of mid-latitude air masses from North America occurred (L2). Both clusters of air parcels experienced fast inter-continental transport along the jet stream. Furthermore, the trajectories of SPF24 confirm the occurrence of a stratospheric intrusion into the troposphere on 24 August. The sources of the air masses probed for these dates are further discussed in the next section.
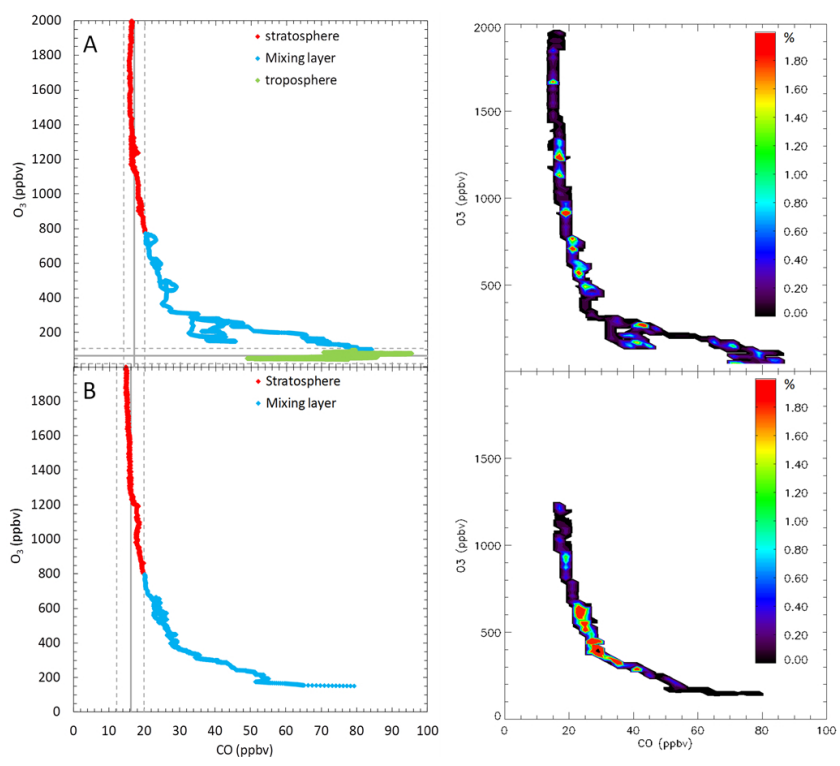

Fig. 6. Correlation between $\mathrm{O}_{3}$ and $\mathrm{CO}$ from SPIRALE in situ measurements, (A) on 7 August 2009, and (B) on 24 August 2009. Left panel: correlation with colours corresponding to the measurements in the stratosphere (red colour), in the mixing layer (blue colour) and in the troposphere (green colour). The vertical grey line represents the stratospheric branch and the horizontal one the tropospheric branch; the dashed lines represent the $3 \sigma$ deviation from the linear fit of the branches. Right panel: correlation with colours corresponding to the joint probability distribution function (PDFs) in $\%$ of the total number of $\mathrm{CO}-\mathrm{O} 3$ pairs between $8 \mathrm{~km}$ above the $T_{\mathrm{p}}$ and $0.6 \mathrm{~km}$ below the $T_{\mathrm{p}}$.

\section{Discussion}

\section{1 $\mathrm{O}_{3}:$ CO correlation}

Tracer-tracer correlations are a powerful diagnosis tool for stratospheric transport and mixing analysis (Hoor et al., 2002; Huret et al., 2006). In particular, we are interested in the $\mathrm{O}_{3}$ : $\mathrm{CO}$ correlation in the upper troposphere-lower stratosphere (UTLS), which has also been used in recent studies for transport diagnoses (Fischer et al., 2000; Hoor et al., 2002; Pan et al., 2004; Pirre et al. 2008; Hegglin et al., 2009; Roiger et al., 2011). CO is mainly produced or emitted in the troposphere and its concentration smoothly decreases with altitude in the stratosphere, reaching a vmr minimum of about 10-15 ppb around 19-22 km altitude. Unlike $\mathrm{CO}, \mathrm{O}_{3}$ is mainly produced in the stratosphere and has consequently a low vmr in the troposphere (below $100 \mathrm{ppb}$, Bethan et al., 1996). Consequently, without mixing between the stratosphere and the troposphere around the tropopause, the correlation between $\mathrm{CO}$ and $\mathrm{O}_{3}$ has an L-shape. This is illustrated by the grey lines in Fig. 6 a (left panel). The vertical line of the " $\mathrm{L}$ " is called the stratospheric branch and its horizontal line the tropospheric branch. Figure 6 shows the correlation between $\mathrm{CO}$ and $\mathrm{O}_{3}$ on 7 August (a) and 24 August (b) 
for SPF07 and SPF24, respectively. We use the CO and $\mathrm{O}_{3}$ simultaneous measurements from SPIRALE. However, as the $\mathrm{O}_{3}$ measurements start only at $14 \mathrm{~km}$ (Fig. 1b), we have completed the lower part of the profile by the measurements from the Vaisala sounding (Sect. 3.1). The correlations of the left panels are divided into different parts: the stratospheric part, the tropospheric part, and the mixing layer. According to Hegglin et al. (2009), the tropospheric branch is defined by $\mathrm{O}_{3} \mathrm{vmr}<100 \mathrm{ppb}$. We choose to define similarly the stratospheric branch as the part of the profile with $\mathrm{CO} v \mathrm{vmr}<20 \mathrm{ppb}$. Both branches are represented by lines based on $\mathrm{CO}$ and $\mathrm{O}_{3}$ averages with uncertainties of $3 \sigma$ and values for $\mathrm{CO} v \mathrm{vmr}>20 \mathrm{ppb}$ and $\mathrm{O}_{3} \mathrm{vmr}>100 \mathrm{ppb}$ defining the mixing layer (Hegglin et al., 2009). Note that the tropospheric branch for SPF24 could not be determined because all $\mathrm{O}_{3}$ values are larger than $100 \mathrm{ppbv}$ over the altitude range with correlative $\mathrm{CO}$ measurements (i.e. $0.6 \mathrm{~km}$ below the $T_{\mathrm{p}}$ ). The Vaisala ozone sonde allowed measurements of $\mathrm{O}_{3}$ at lower altitudes and showed that the $100 \mathrm{ppb}$ limit was reached for altitudes lower than $8.7 \mathrm{~km}$, i.e. $0.8 \mathrm{~km}$ below the local thermal tropopause.

The mixing layer is different for the two flights. For SPF07, the mixing layer is extending from $T_{\mathrm{p}}$ to $\sim 4.8 \mathrm{~km}$ above the $T_{\mathrm{p}}$. For SPF24, the mixing layer is present $\sim 7 \mathrm{~km}$ above the $T_{\mathrm{p}}$ and $\sim 0.8 \mathrm{~km}$ below the $T_{\mathrm{p}}$. The origin of the air masses for these mixing layers is also very different, as explained in Sect. 3.4.2. The right panels of Fig. 6 represent the probability distribution function in percentage of all the measurements for altitude between $8 \mathrm{~km}$ above the $T_{\mathrm{p}}$ and $0.6 \mathrm{~km}$ below the $T_{\mathrm{p}}$. The distribution of the correlation points is more uniform in the mixing layer for SPF07 than for SPF24, with CO vmr more likely included in the range $[20,80] \mathrm{ppb}$ and $\mathrm{O}_{3} \mathrm{vmr}$ in the range $[100,700] \mathrm{ppb}$ in the first case, while $[20,40] \mathrm{ppb} \mathrm{CO}$ and $[300,700] \mathrm{ppb} \mathrm{O}_{3}$ are more observed in the second case. As seen in Sect. 3.4.2., air masses for SPF07 are indeed coming from mid-latitude troposphere and stratosphere, whereas air is more from stratospheric polar origin for SPF24, confirming the stratospheric intrusion in the latter case.

\subsection{The L1 layer origin}

The objective of this section is to characterize the $\mathrm{CO}$ sources (urban pollution and/or fires) responsible for the polluted L1 layer observed by SPIRALE on 7 August.

\subsubsection{Anthropogenic and natural CO sources}

Figure 7 shows the evolution of IASI CO total column from 28 July (10 days before the flight) to 7 August in the Northern Hemisphere. At the end of July, the CO transport from East Asia is well illustrated in this figure and the localisation of the air masses (of L1) is highlighted by black circles (clusters A resulting from FLEXTRA simulation, Sect. 3.4.2). At the beginning, the CO plume is located at $105-160^{\circ} \mathrm{E}$ and $30-65^{\circ} \mathrm{N}$ over East Asia and Siberia. It has $\mathrm{CO}$ total columns higher than $3.25 \times 10^{18}$ molecules $\mathrm{cm}^{-2}$ (Fig. 7a). Figure 7b illustrates the plume pollution transport across the Pacific Ocean from Asia $\left(180^{\circ} \mathrm{E}-40^{\circ} \mathrm{N}\right)$ to North America $\left(-130^{\circ} \mathrm{E}-65^{\circ} \mathrm{N}\right)$ during two days (31 July and 1 August). Then the pollution crosses North America toward the Atlantic Ocean (Fig. 7c). CO total column values are lower than values found 6 days before but still significant $\left(>2.25 \times 10^{18}\right.$ molecules $\left.\mathrm{cm}^{-2}\right)$. Starting from $5 \mathrm{Au}$ gust 2009, a long tongue of $\mathrm{CO}$ with columns higher than $2.25 \times 10^{18}$ molecules $\mathrm{cm}^{-2}$ appears over the Atlantic Ocean (in green colour in Fig. 7d). Two days before the intrusion of 7 August, the CO plume is located in the middle of the Atlantic Ocean $\left(40-50^{\circ} \mathrm{N}\right)$ and over Western Europe. Then the pollution intrusion crosses Northern Europe with CO total column between $2.00 \times 10^{18}$ and $2.50 \times 10^{18}$ molecules $\mathrm{cm}^{-2}$ on 7 August 2009.

Figure 7 reveals several areas of high $\mathrm{CO}$ concentration (with columns $>2.8 \times 10^{18}$ molecules $\mathrm{cm}^{-2}$ ) along the air mass trajectories (black circle), over northern East Asia and over North America. To identify the origin of the pollution, we used, in addition to $\mathrm{CO}$, ammonia $\left(\mathrm{NH}_{3}\right)$ columns from IASI and fires detection from MODIS. Indeed, $\mathrm{CO}$ is mainly emitted from biomass burning, fuel consumption, industry and from in situ oxidation of organics (Seinfeld and Pandis, 2006). Agriculture and biomass burning are the main sources of $\mathrm{NH}_{3}$ (Bouwman et al., 1997). Consequently, $\mathrm{NH}_{3}$ and $\mathrm{CO}$ have only one source in common, biomass burning, whereas the other sources are quite incompatible. $\mathrm{NH}_{3}$ total column coupled with other gas tracers such as $\mathrm{CO}$ has already been used by Coheur et al. (2009) to highlight the strong fires that have occurred in the Mediterranean Basin in August 2007. These authors showed the good correlation between the $\mathrm{CO}$ and $\mathrm{NH}_{3}$ emissions when the Greek fires occurred. In order to identify the geographical area of biomass burning from 10 to 5 days before the flight, $\mathrm{NH}_{3}$ and $\mathrm{CO}$ maps are coupled with fire detection maps from MODIS shown in Fig. 8. The comparison between the $\mathrm{CO}$ and $\mathrm{NH}_{3}$ distributions highlights two areas of high concentrations for both species along the air mass trajectories (labelled by dates with black circles in Fig. 8): one over Siberia $\left(130-160^{\circ} \mathrm{E}, 60-65^{\circ} \mathrm{N}\right)$ and the other one over Alaska-Canada $\left((-125)-\left(-155^{\circ}\right) \mathrm{E}, 50\right.$ $\left.70^{\circ} \mathrm{N}\right)$. The correlation between $\mathrm{CO}$ and $\mathrm{NH}_{3}$ plumes suggests a biomass burning origin for the enhanced concentrations, and not high $\mathrm{CO}$ concentrations due to the imported pollution from other regions. This is further confirmed by the location of the MODIS fire counts (Fig. 8, bottom).

We thus have three candidate regions for pollution to explain the unusual $\mathrm{CO}$ measurements in the polar atmosphere: anthropogenic emissions from East Asia, and fire emissions from Alaska-Canada and Siberia. In addition, backwardtrajectory calculations (Sect. 3.4.2, Fig. 5a, left) have shown pollution from North America origin. In the next section, we test the relative impact of each region on the polar atmosphere on 7 August 2009 for L1. 

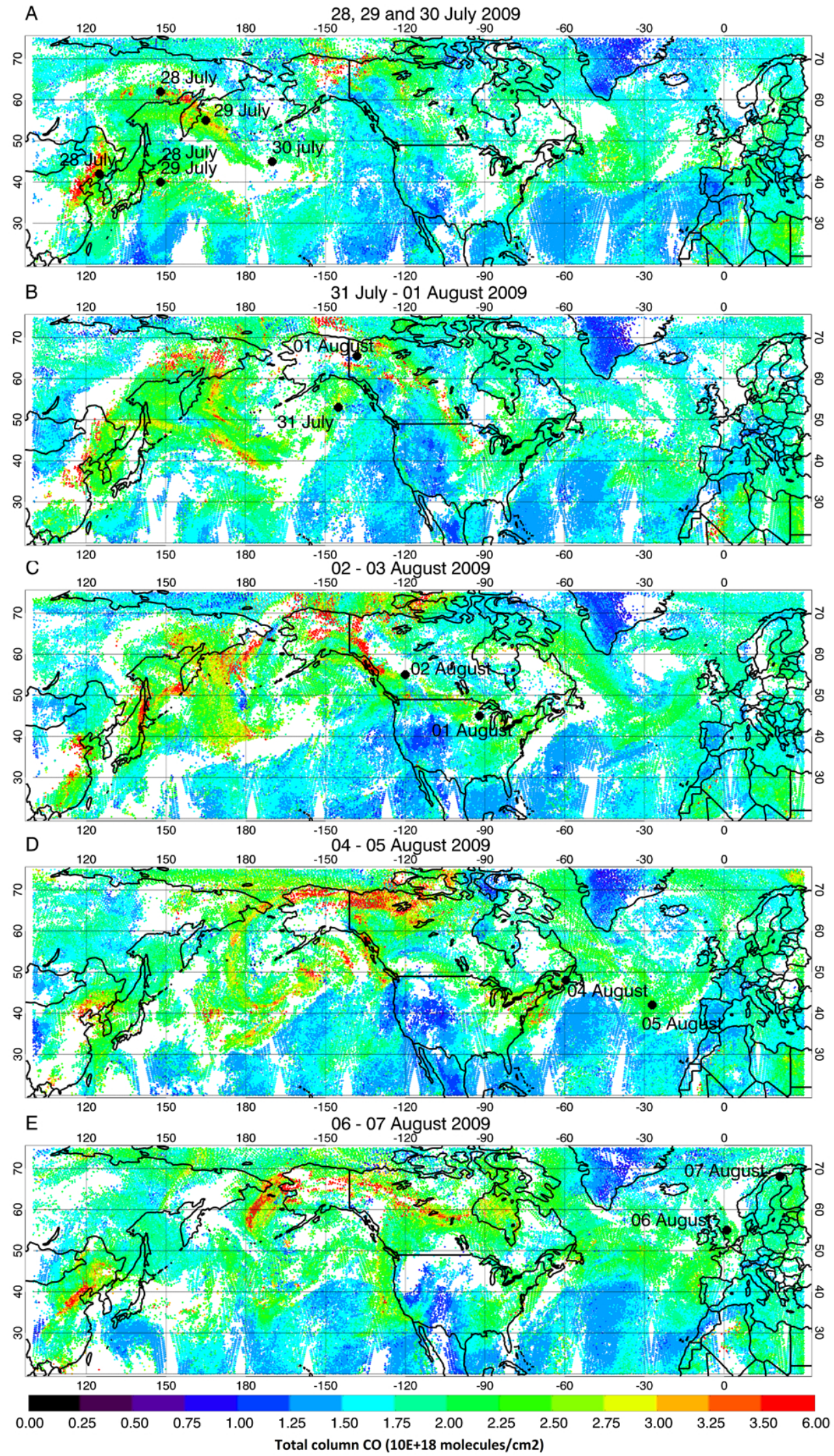

Fig. 7. CO total column (molecules $\mathrm{cm}^{-2}$ ) from IASI-MetOp satellite evolution from 29 July 2009 (A) to 7 August 2009 (E). The circles indicate the location of the air masses before the flight day (clusters A and B resulting from FLEXTRA simulation). 

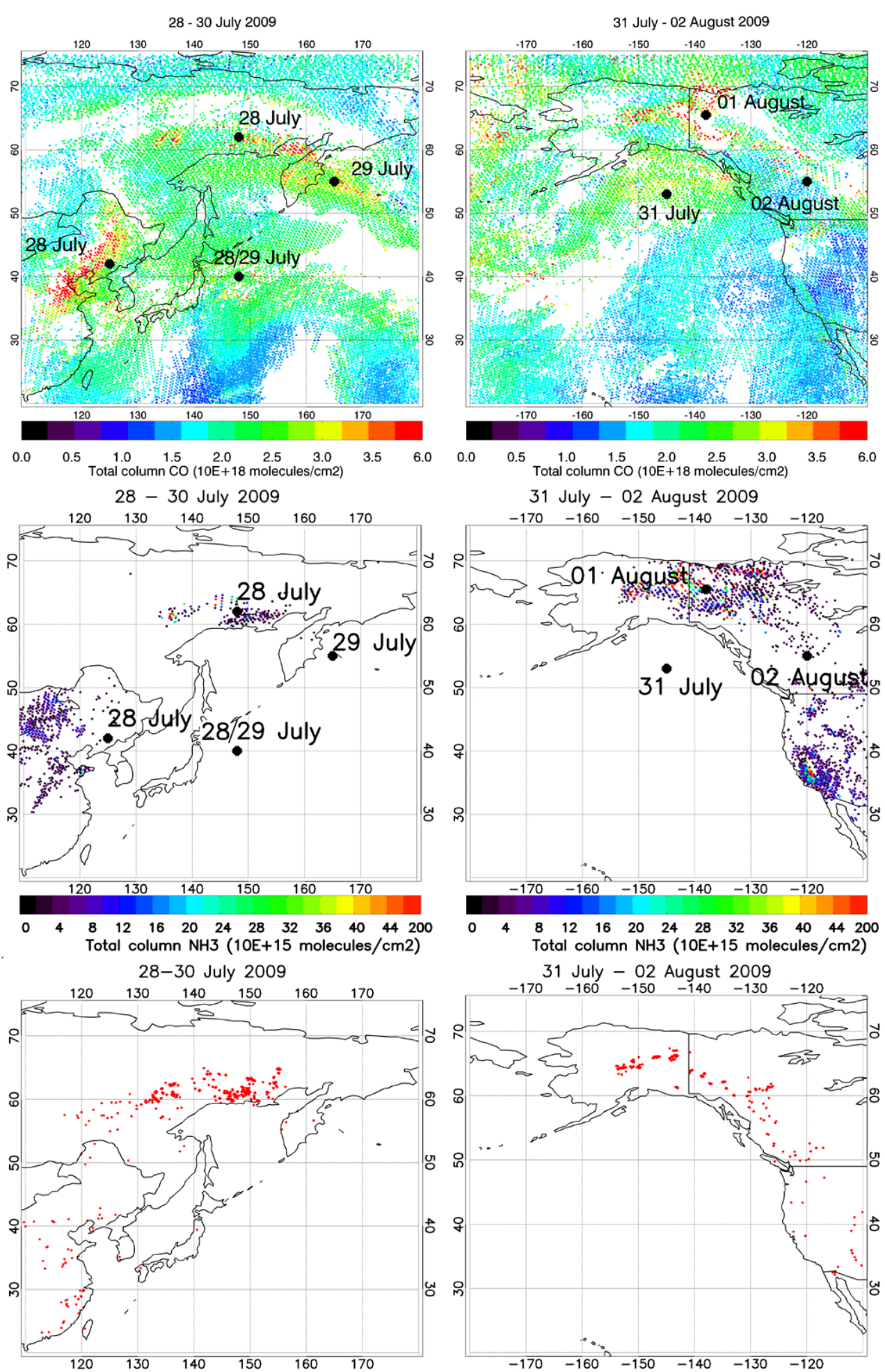

Fig. 8. $\mathrm{CO}$ and $\mathrm{NH}_{3}$ total column (molecules $\mathrm{cm}^{-2}$ ) (top and middle panels) from the IASI instrument and fire detection by MODIS (bottom panels) (each red point symbolizes a fire location) from 29 to 30 July 2009 over north of East Asia (left panels) and from 31 July to 2 August 2009 over North America (right panels). The circles indicate the location of the air masses before the flight day (clusters A and B resulting from FLEXTRA simulation). 
Table 2. Additional $\mathrm{CO}$ volume mixing ratio (ppb) in the intrusion on 7 August 2009 (difference between CO (7 August) and CO (24 August)), at $-500 \mathrm{~m}$ (L1 A, Fig. 3) and $+250 \mathrm{~m}$ (L1 B, Fig. 3) relative altitudes to the thermal tropopause $\left(T_{\mathrm{p}}\right)$. Simulation 1 is with a mask (\#1) over East Asia; simulation 2 with a mask (\#2) over North America. See text (Sect. 4.2.2) for details.

\begin{tabular}{|c|c|c|c|}
\hline \multirow[b]{2}{*}{ Simulation } & \multirow[b]{2}{*}{ Region } & $+250 \mathrm{~m}$ & $-500 \mathrm{~m}$ \\
\hline & & $\begin{array}{l}\mathrm{CO}(7 \mathrm{Aug})- \\
\mathrm{CO}(24 \mathrm{Aug})\end{array}$ & $\begin{array}{l}\mathrm{CO}(7 \mathrm{Aug})- \\
\mathrm{CO}(24 \mathrm{Aug})\end{array}$ \\
\hline Control run & World & $32(100 \%)$ & $30(100 \%)$ \\
\hline 1 & East Asia & $7(22 \%)^{*}$ & $8.8(29 \%)^{*}$ \\
\hline 2 & North America & $1(3 \%)^{*}$ & $19(63 \%)^{*}$ \\
\hline 3 & Fires & $0(0 \%)$ & $0(0 \%)$ \\
\hline
\end{tabular}

* Proportion of air from the source region in the intrusion over Kiruna on 7 August 2009.

\subsubsection{CO emission regional distribution determined by simulation}

To evaluate the potential impact of these anthropogenic and natural sources, we have performed simulations using the REPROBUS CTM. Three different masks were applied on MOPITT CO analyses used by REPROBUS as $\mathrm{CO}$ source at $500 \mathrm{hPa}$. In simulations 1, 2 and 3, only East Asia $\left(105-150^{\circ} \mathrm{E}, 20-45^{\circ} \mathrm{N}\right)$ emissions, Northern America $\left((-75)-\left(-120^{\circ}\right)\right.$ E, $\left.30-45^{\circ} \mathrm{N}\right)$ emissions, and SiberiaAlaska-Canada fire emissions were taken into account, respectively. We performed a control run using the global MOPITT CO climatology. Figure 9 shows the spatial extension of masks. The test results are shown in Table 2 for two different altitudes corresponding to the top ( $250 \mathrm{~m}$ above the $T_{\mathrm{p}}$ ) and the bottom ( $500 \mathrm{~m}$ below the $T_{\mathrm{p}}$ ) of $\mathrm{L} 1$.

The first simulation (Mask 1) tests the impact of the East Asia CO emission on the polar UTC/LMS. The value on 7 August is larger by $7 \mathrm{ppb}$ at $250 \mathrm{~m}$ above the $T_{\mathrm{p}}$ and $8.8 \mathrm{ppb}$ at $500 \mathrm{~m}$ below the $T_{\mathrm{p}}$ than the value on 24 August. In the control case, this difference is increased by a factor of 4 (larger by $30 \mathrm{ppb}$ ) and therefore the L1 pollution is not exclusively explained by these Asia $\mathrm{CO}$ emissions. According to the FLEXTRA backward trajectories (Sect. 3.4.2., Fig. 5), we considered that on 24 August 2009 the air masses are coming only from the polar latitudes. Consequently, we can consider the air masses of 24 August 2009 as typical background polar air (with different origins). So, the difference between the 7 and 24 August for REPROBUS simulation 1 is only due to the intrusion and we can calculate the proportion of air from East Asia in the intrusion. We found 23 and $30 \%$ of $\mathrm{CO}$ in the air mass present in the L1 layer on 7 August 2009 over Kiruna originate from anthropogenic East Asia pollution for altitude $250 \mathrm{~m}$ above the $T_{\mathrm{p}}$ (L1 B, Fig. 3) and for altitude $500 \mathrm{~m}$ below the $T_{\mathrm{p}}$ (L1 A, Fig. 3), respectively.
Similarly, simulation 2 tests the impact of North America emissions on polar UTC/LMS. The CO vmr on 7 August is larger by $1 \mathrm{ppb}$ at $250 \mathrm{~m}$ above the $T_{\mathrm{p}}$ and $19 \mathrm{ppb}$ at $500 \mathrm{~m}$ below the $T_{\mathrm{p}}$ compared to 24 August. As previously, we can calculate the proportion of $\mathrm{CO}$ originating from North America in the intrusion. Totals of 3 and $60 \%$ of $\mathrm{CO}$ in the air mass present on 7 August 2009 over Kiruna originate from North America for altitudes $250 \mathrm{~m}$ above the $T_{\mathrm{p}}$ and $500 \mathrm{~m}$ below the $T_{\mathrm{p}}$, respectively.

And finally, simulation 3 tests the impact of fires emissions from Siberia, Canada and Alaska on polar UTC/LMS. No differences are observed between the flights. So, the fires in these regions have the same influence for both flights.

According to the simulations, the air masses sampled in the L1 mainly come from anthropogenic emissions. The stratospheric part of $\mathrm{L} 1\left(250 \mathrm{~m}\right.$ above the $\left.T_{\mathrm{p}}\right)$ is more influenced by East Asia than North America pollution, while the tropospheric part ( $500 \mathrm{~m}$ below the $T_{\mathrm{p}}$ ) is influenced less by East Asia than by North America pollution. The fires in Alaska, Canada and Siberia have a negligible influence on the CO vmr in the intrusion. This is also in agreement with the FLEXTRA trajectories (Sect. 3.4.2 and Fig. 5), which show that the Alaska-Canada fire emissions influence equally SPF07 and SPF24.

Some care has to be given to the above analyses, given that the REPROBUS CO concentrations are nudged by the monthly CO climatology at $500 \mathrm{hPa}$ level. $\mathrm{CO}$ at this level could have several origins corresponding to regional or longrange transport. All CO pollution coming from nearby regions, e.g. biomass burning in Alaska-Canada $((-125)-$ $\left(-155^{\circ}\right) \mathrm{E}, 50-70^{\circ} \mathrm{N}$ ) (Wotawa et al., 2000) or CO transport across the Pacific Ocean, Liang et al., 2004), and crossing the mask have been taken into account in our calculation. So, the relative parts of the long-range transport have to be taken as maxima.

\section{Conclusions and perspectives}

Eight balloon flights were launched during the StraPolÉté campaign between 2 August and 12 September 2009 from ESRANGE base (Swedish Space Corporation) close to Kiruna, Sweden. Among these flights, the SPIRALE instrument flew twice, on 7 August and on 24 August. In addition, the SWIR-balloon instrument flew on 14 August.

The altitude of the tropopause has been identified for the StrapolÉté campaign according to several definitions (thermal tropopause and dynamical tropopause) to discuss in detail the troposphere/stratosphere exchange.

CO total column satellite data from IASI-MetOp instrument for the three dates of flights were used to understand the spatial and temporal $\mathrm{CO}$ variability observed during the three balloon flights. IASI measures comparable low CO concentrations on 14 and 24 August and much higher values on 7 August. SPIRALE and SWIR CO partial columns between 


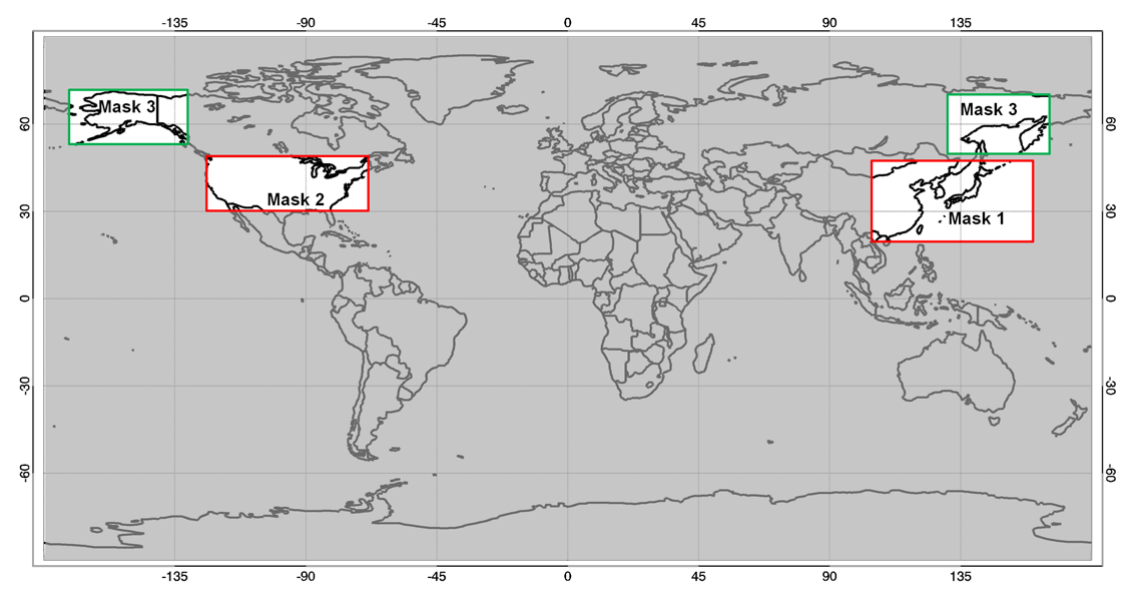

Fig. 9. Spatial extensions of mask 1, mask 2 and mask 3: the $\mathrm{CO}$ emissions in the grey part are not taken into account for simulation 1 or 2 or 3, depending on the mask. The green mask (\#3) takes into account more fire emissions and the red masks (\#1, \#2) more anthropogenic emissions.

9 and $34 \mathrm{~km}$ were compared and allowed us to confirm that the enhancement of $\mathrm{CO}$ is localised in the stratosphere.

The SPIRALE balloon-borne instrument observations in the lower stratosphere on 7 August showed two layers of air with very high CO levels (volume mixing ratios near $80 \mathrm{ppb}$ ). The layers extend over the potential temperature range [320, $380] \mathrm{K}(10-14 \mathrm{~km})$, with the CO maximum of $80 \mathrm{ppb}$ at $330 \mathrm{~K}(11.4 \mathrm{~km})$. The $\mathrm{CO}$ mixing ratio in the range [50, $80] \mathrm{ppb}$ is typical from mid-latitude values. These CO data are consistent with poleward intrusions from mid-latitudes represented by low PV region detected at $340 \mathrm{~K}$ and $380 \mathrm{~K}$, as shown by MIMOSA model. Ten days backward trajectories between 10.5 and $15 \mathrm{~km}$ from Kiruna were calculated by using FLEXTRA model. The upper layer, extending from 12.6 to $14 \mathrm{~km}$, is associated with air mass intrusion from mid-latitudes (North America). Air masses of the lower layer, below $12.6 \mathrm{~km}(\mathrm{~L} 1)$, were shown to originate from East Asia and North America, entering the polar UTLS by fast transport from the mid-latitude lower levels (altitude $<4 \mathrm{~km}$ ) into free troposphere, followed by isentropic transport. The $\mathrm{O}_{3}: \mathrm{CO}$ correlation of the two flights of SPIRALE confirmed that a recent mixing with tropospheric air occurred in the region called mixing layer on 7 August 2009 and mixing with stratospheric air occurred on 24 August 2009.

We have also investigated the origin, evolution and transport of air masses of the lower layer (L1, i.e. below $12.6 \mathrm{~km}$ ). The plume pollution was ascending over West Pacific near Japan and North America. After the initial ascent, the plume crossed the North Pacific Ocean, North America, and the North Atlantic Ocean in a fast zonal flow. IASI-MetOp measurements were also used to detect where high CO concentrations occurred and allowed us to provide information on the origins of $\mathrm{CO}$ source. The $\mathrm{CO}$ total column maps were combined with $\mathrm{NH}_{3}$ distributions from IASI and fire counts from
MODIS and were used to detect anthropogenic area emission over East Asia and North America and biomass burning regions over Siberia and Alaska-Canada as potential CO sources impacting the polar region.

To evaluate the potential impact of these anthropogenic and natural sources on the air masses of the intrusion, we have performed simulations using the REPROBUS CTM. According to all the simulations, the air masses present in the lower layer (L1) mainly come from anthropogenic emissions. The stratospheric part of L1 (11.7-12.6 km, Fig. 3) is more influenced by East Asia than North America pollution, while the reverse is true for the tropospheric part $(10.5-11.7 \mathrm{~km}$, Fig. 3) of the profile. The fires over Siberia and AlaskaCanada have negligible influence on the $\mathrm{CO} v m r$ present in the intrusion.

In this study, only one case was described. However, in August 2009 there were two other similar phenomena simulated by MIMOSA model and shown by ozone sounding on 21 and 29 August. Therefore, the 7 August 2009 intrusion might not be an isolated case. The climatology of the intrusions during several summers should be established to better study the impact of urban mid-latitude pollution on the Arctic regions. Studies using trajectory models have very recently evaluated the impact of three regions, namely Europe, USA and East China on the Arctic (e.g. Harrigan et al., 2011).

Acknowledgements. The authors thank the LPC2E technical team (L. Pomathiod, B. Gaubicher, G. Chalumeau, B. Coûté, T. Vincent and F. Savoie) for the SPIRALE instrument preparation, the LPMAA technical team (I. Pépin, C. Rouillé and P. Marie-Jeanne) for the SWIR-balloon instrument preparation, the CNES balloon launching team and the Swedish Space Corporation at Esrange for successful operations, and A. Hauchecorne and F. Lefèvre for making available the MIMOSA and REPROBUS models. The 
ETHER database (Pôle thématique du CNES-INSU-CNRS) and the "CNES sous-direction Ballon" are partners of the project. The StraPolÉté project was funded by the French "Agence Nationale de la Recherche" (ANR-BLAN08-1-31627), the "Centre National d'Etudes Spatiales" (CNES), and the "Institut Polaire Paul-Emile Victor" (IPEV). In general, we acknowledge the mission scientists and Principal Investigators who provided the data used in this research effort (MODIS). IASI has been developed and built under the responsibility of the CNES. It is flown on board the MetOp satellites as part of the EUMETSAT Polar System. The IASI L1 data are received through the EUMETCast near-real-time data distribution service. Part of the work on IASI was supported by EUMETSAT through the O3SAF project. P. F. Coheur is Research Associate with F. R. S.-FNRS and its research is also funded by the Belgian State Federal Office for Scientific, Technical and Cultural Affairs and the European Space Agency (ESA-Prodex arrangement), and the Actions de Recherche Concertées (Communauté Française de Belgique). Cathy Clerbaux is grateful to CNES for scientific collaboration and financial support. L. Clarisse, J. HadjiLazaro, D. Hurtmans, M. George, Y. Ngadi and M. Van Damme are acknowledged for scientific development and maintenance of the $\mathrm{CO}$ and $\mathrm{NH}_{3}$ products from IASI.

Edited by: A. Engel

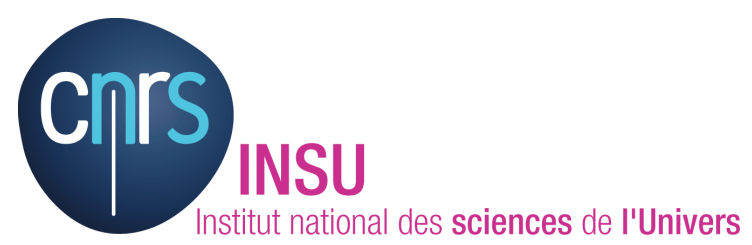

The publication of this article is financed by CNRS-INSU.

\section{References}

Akimoto, H.: Global Air Quality and Pollution, Science, 302, 17161719, 2003.

Baldwin, M. P., Dameris, M., and Shepherd, T. G.: How will the stratosphere affect climate change?, Science, 316, 1576-1577, 2007.

Bekki, S. and Pyle, J. A.: Potential impact of combined $\mathrm{NO}_{\mathrm{x}}$ and $\mathrm{SO}_{\mathrm{x}}$ emissions from future high speed civil transport aircraft on stratospheric aerosols and ozone, Geophys. Res. Lett., 20, 723726, 1993.

Bekki, S. and Pyle, J. A.: A two-dimensional modeling study of the volcanic eruption of mount Pinatubo, J. Geophys. Res., 99, 861-869, 1994.

Berntsen, T. K., Karlsdottir, S., and Jaffe, D. A.: Influence of Asian emissions on the composition of air reaching the North Western United States, J. Geophys. Res., 26, 2171-2174, 1999.

Bethan, S., Vaughan, G., and Reid, S. J.: A comparison of ozone and thermal tropopause heights and the impact of tropopause definition on quantifying the ozone C5694 content of the troposphere, Q. J. R. Meteorol. Soc., 122, 929-944, 1996.

Bouwman, A. F, Lee, D . S, Asman, W . A. H., Dentener, F . J., Van Der Hoek K. W., and Olivier, J. G. J.: A global high-resolution emission inventory for ammonia, Global Biogeochem. Cy., 11, 561-587, 1997.

Brioude, J., Cammas, J.-P., and Cooper, O. R.: Stratospheretroposphere exchange in a summertime extratropical low: analysis, Atmos. Chem. Phys., 6, 2337-2353, doi:10.5194/acp-62337-2006, 2006.

Brock, C. A., Cozic, J., Bahreini, R., Froyd, K. D., Middlebrook, A. M., McComiskey, A., Brioude, J., Cooper, O. R., Stohl, A., Aikin, K. C., de Gouw, J. A., Fahey, D. W., Ferrare, R. A., Gao, R.-S., Gore, W., Holloway, J. S., Hübler, G., Jefferson, A., Lack, D. A., Lance, S., Moore, R. H., Murphy, D. M., Nenes, A., Novelli, P. C., Nowak, J. B., Ogren, J. A., Peischl, J., Pierce, R. B., Pilewskie, P., Quinn, P. K., Ryerson, T. B., Schmidt, K. S., Schwarz, J. P., Sodemann, H., Spackman, J. R., Stark, H., Thomson, D. S., Thornberry, T., Veres, P., Watts, L. A., Warneke, C., and Wollny, A. G.: Characteristics, sources, and transport of aerosols measured in spring 2008 during the aerosol, radiation, and cloud processes affecting Arctic Climate (ARCPAC) Project, Atmos. Chem. Phys., 11, 2423-2453, doi:10.5194/acp-11-24232011, 2011.

Claeyman, M., Attié, J.-L., El Amraoui, L., Cariolle, D., Peuch, V.H., Teyssèdre, H., Josse, B., Ricaud, P., Massart, S., Piacentini, A., Cammas, J.-P., Livesey, N. J., Pumphrey, H. C., and Edwards, D. P.: A linear CO chemistry parameterization in a chemistrytransport model: evaluation and application to data assimilation, Atmos. Chem. Phys., 10, 6097-6115, doi:10.5194/acp-10-60972010, 2010.

Clarisse, L., Shephard, M. W., Dentener, F., Hurtmans, D., CadyPereira, K., Karagulian, F., Van Damme, M., Clerbaux, C., and Coheur, P. F: Satellite monitoring of ammonia: A case study of the San Joaquin Valley, J. Geophys. Res. Atmos., 115, D13302, doi:10.1029/2009JD013291, 2010.

Clarisse, L., R'Honi, Y., Coheur, P. F., Hurtmans, D., and Clerbaux, $C$ : Thermal infrared nadir observations of 24 atmospheric gases., Geophys. Res. Lett., 38, L10802, doi:10.1029/2011GL047271, 2011.

Clerbaux, C., Hadji-Lazaro, J., Payan, S., Camy-Peyret C., and Mégie, G.: Retrieval of CO columns from IMG/ADEOS spectra, IEEE T. Geosci. Remote, 37, 1657-1661, 1999.

Clerbaux, C., Boynard, A., Clarisse, L., George, M., Hadji-Lazaro, J., Herbin, H., Hurtmans, D., Pommier, M., Razavi, A., Turquety, S., Wespes, C., and Coheur, P.-F.: Monitoring of atmospheric composition using the thermal infrared IASI/MetOp sounder, Atmos. Chem. Phys., 9, 6041-6054, doi:10.5194/acp-9-6041-2009, 2009.

Coheur, P.-F., Clarisse, L., Turquety, S., Hurtmans, D., and Clerbaux, C.: IASI measurements of reactive trace species in biomass burning plumes, Atmos. Chem. Phys., 9, 5655-5667, doi:10.5194/acp-9-5655-2009, 2009.

Cooper, O. R., Forster, C., Parrish, D., Trainer, M., Dunlea, E., Ryerson, T., Hübler, G., Fehsenfeld, F., Nicks, D., Holloway, J., de Gouw, J., Warneke, C., Roberts, J. M., Flocke, F., and Moody, J.: A case study of transpacific warm conveyor belt transport: Influence of merging airstreams on trace gas import to North America, J. Geophys. Res., 109, D23S08, doi:10.1029/2003JD003624, 2004.

Dee, D. P., Uppala, S. M., Simmons, A. J., P. Berrisford, Poli, P., Kobayashi, S., Andrae, U., Balmaseda, M. A., Balsamo, G., Bauer, P., Bechtold, P., M. Beljaars, A. C., van de Berg, L., Bid- 
lot, J., Bormann, N., Delsol, C., Dragani, R., Fuentes, M., Geer, A. J., Haimberger, L., Healy, S. B., Hersbach, H., Holm, E. V., Isaksen, L., Kallberg, P., Kohler, M., Matricardi, M., McNally, A. P., Monge-Sanz , B. M., Morcrette, J.-J., Park, B.-K., Peubey, C., de Rosnay, P., Tavolato, C., Thepaut, J.-N., and Vitart, F.: The ERA-Interim reanalysis: configuration and performance of the data assimilation system, Q. J. R. Meteorol. Soc., 137, 553-597, 2011

Deeter, M. N., Emmons, L. K., Francis, G. L., Edwards, D. P., Gille, J. C., Warner, J. X., Khattatov, B., Ziskin, D., Lamarque, J. F., Ho, S. P., Yudin, V., Attié, J. L., Packman, D., Chen, J., Mao, D., and Drummond, J. R.: Operational carbon monoxide retrieval algorithm and selected results for the MOPITT instrument, J. Geophys. Res., 108, 4399, doi:10.1029/2002JD003186, 2003.

Deeter, M. N., Edwards, D. P., Gille, J. C., Emmons, L. K., Francis, G., Ho, S.-P., Mao, D., Masters, D., Worden, H., Drummond, J. R., and Novelli, P. C.: The MOPITT version 4 CO product: Algorithm enhancements, validation, and long-term stability, J. Geophys. Res., 115, D07306, doi:10.1029/2009JD013005, 2010.

Durry, G. and Hauchecorne, A.: Evidence for long-lived polar vortex air in the mid-latitude summer stratosphere from in situ laser diode $\mathrm{CH} 4$ and $\mathrm{H} 2 \mathrm{O}$ measurements, Atmos. Chem. Phys., 5, 1467-1472, doi:10.5194/acp-5-1467-2005, 2005.

Elliott, S., Blake, D. R., Duce, R. A., Lai, C. A., McCreary, I., McNair, L. ARowland, F. S., Russell, A. G., Streit, G. E., and Turco, R. P.: Motorization of China implies changes in Pacific air chemistry and primary production, Geophys. Res. Lett., 24, 2671-2674, doi:10.1029/97GL02800, 1997.

Engel, A., Bönisch, H., Brunner, D., Fischer, H., Franke, H., Günther, G., Gurk, C., Hegglin, M., Hoor, P., Königstedt, R., Krebsbach, M., Maser, R., Parchatka, U., Peter, T., Schell, D., Schiller, C., Schmidt, U., Spelten, N., Szabo, T., Weers, U., Wernli, H., Wetter, T., and Wirth, V.: Highly resolved observations of trace gases in the lowermost stratosphere and upper troposphere from the Spurt project: an overview, Atmos. Chem. Phys., 6, 283-301, doi:10.5194/acp-6-283-2006, 2006.

Fiedler, V., Nau, R., Ludmann, S., Arnold, F., Schlager, H., and Stohl, A.: East Asian $\mathrm{SO}_{2}$ pollution plume over Europe - Part 1: Airborne trace gas measurements and source identification by particle dispersion model simulations, Atmos. Chem. Phys., 9, 4717-4728, doi:10.5194/acp-9-4717-2009, 2009.

Fischer, H., Wienhold, G., Hoor, P., Bujok, O., Schiller, C., Siegmund, P., Ambaum, M., Scheeren, H. A., and Lelieveld, J.: Tracer correlations in the northern high latitude lowermost stratosphere: Influence of cross tropopause masse exchange, Geophys. Res. Lett., 27, 97-100, 2000.

Forster, P. M. D. E. F. and Joshi, M.: The Role of Halocarbons In The Climate Change of The Troposphere And Stratosphere, Climatic Change, 71, 249-266, doi:10.1007/s10584-005-59557, 2005.

George, M., Clerbaux, C., Hurtmans, D., Turquety, S., Coheur, P.F., Pommier, M., Hadji-Lazaro, J., Edwards, D. P., Worden, H., Luo, M., Rinsland, C., and McMillan, W.: Carbon monoxide distributions from the IASI/METOP mission: evaluation with other space-borne remote sensors, Atmos. Chem. Phys., 9, 8317-8330, doi:10.5194/acp-9-8317-2009, 2009.

Gettelman, A., Hoor, P., Pan, L. L., Randel, W. J., Hegglin, M. I., and Birner, T.: The extratropical upper troposphere and lower stratosphere, Rev. Geophys., 49, RG3003,
doi:10.1029/2011RG000355, 2011.

Giglio, L., Descloitres, J., Justice, C. O., and Kaufman, Y. J.: An enhanced contextual firedetection algorithm for MODIS, Remote Sens. Environ., 87, 273-282, http://modis-fire.umd.edu, 2003.

Harrigan, D. L., Fuelberg, H. E., Simpson, I. J., Blake, D. R., Carmichael, G. R., and Diskin, G. S.: Anthropogenic emissions during Arctas-A: mean transport characteristics and regional case studies, Atmos. Chem. Phys., 11, 8677-8701, doi:10.5194/acp11-8677-2011, 2011.

Hauchecorne, A., Godin, S., Marchand, M., Heese, B., and Souprayen, C.: Quantification of the transport of chemical constituents from the polar vortex to midlatitudes in the lower stratosphere using the high-resolution advection model MIMOSA and effective diffusivity, J. Geophys. Res., 107, 8289, doi:10.1029/2001JD000491, 2002.

Hegglin, M. I., Brunner, D., Peter, T., Hoor, P., Fischer, H., Staehelin, J., Krebsbach, M., Schiller, C., Parchatka, U., and Weers, U.: Measurements of $\mathrm{NO}, \mathrm{NO}_{\mathrm{y}}, \mathrm{N}_{2} \mathrm{O}$, and $\mathrm{O}_{3}$ during SPURT: implications for transport and chemistry in the lowermost stratosphere, Atmos. Chem. Phys., 6, 1331-1350, doi:10.5194/acp-61331-2006, 2006.

Hegglin, M. I., Boone, C. D., Manney, G. L., and Walker, K. A.: A global view of the extratropical tropopause transition layer from Atmospheric Chemistry Experiment Fourier Transform Spectrometer $\mathrm{O}_{3}, \mathrm{H}_{2} \mathrm{O}$, and CO, J. Geophys. Res., 114, D00B11, doi:10.1029/2008JD009984, 2009.

Hoerling, M. P., Schaack, T. K., and Lenzen, A. J.: Global objective tropopause analysis, Mon. Weather Rev., 119, 1816-1831, doi:10.1175/1520-0493(1991)119;1816:GOTA ¿2.0.CO;2, 1991.

Holton, J. R., Haynes, P. H., Mcintyre, M. E., Douglass, A. R., Rood, R. B., and Pfister, L.: Stratosphere-troposphere exchange, Rev. Geophys., 33, 403-439, 1995.

Hoor, P., Fischer, H., Lange, L., Lelieveld, J., and Brunner, D.: Seasonal variation of a mixing layer in the lowermost stratosphere as identified by the $\mathrm{CO}-\mathrm{O}_{3}$ correlation from in situ measurements, J. Geophys. Res., 107, 4044-4055, doi:10.1029/2000JD000289, 2002.

Huret, N., Pirre, M., Hauchecorne, A., Robert, C., and Catoire, V.: On the vertical structure of the stratosphere at midlatitudes during the first stage of the polar vortex formation and in the polar region in the presence of a large mesospheric descent, J. Geophys. Res., 111, D06111, doi:10.1029/2005JD006102, 2006.

Hurtmans, D., Coheur, P. F., Wespes, C., Clarisse, L., Scharf, O., Clerbaux, C., Hadji-Lazaro, J., George, M., and Turquety, S.: FORLI radiative transfer and retrieval code for IASI, J. Quant. Spectrosc. Rad. Transfer, 113, 1391-1408, doi:10.1016/j.jqsrt.2012.02.036, 2012.

Jacob, D. J., Crawford, J. H., Maring, H., Clarke, A. D., Dibb, J. E., Emmons, L. K., Ferrare, R. A., Hostetler, C. A., Russell, P. B., Singh, H. B., Thompson, A. M., Shaw, G. E., McCauley, E., Pederson, J. R., and Fisher, J. A.: The Arctic Research of the Composition of the Troposphere from Aircraft and Satellites (ARCTAS) mission: design, execution, and first results, Atmos. Chem. Phys., 10, 5191-5212, doi:10.5194/acp-10-5191-2010, 2010.

Jaffe, D., Anderson, T., Covert, D., Kotchenruther, R., Trost, B., Danielson, J., Simpson, W., Berntsen,T., Karlsdottir, S., Blake, D., Harris, J., Carmichael, G., and Uno, I.: Transport of Asian Air Pollution to North America, Geophys. Res. Lett., 26, $711-$ 714, 1999. 
Jourdain, L., Bekki, S., Lott, F., and Lefèvre, F.: The coupled chemistry-climate model LMDz-REPROBUS: description and evaluation of a transient simulation of the period 1980-1999, Ann. Geophys., 26, 1391-1413, doi:10.5194/angeo-26-13912008, 2008.

Lefèvre, F., Brasseur, G. P., Folkins, I., Smith, A. K., and Simon, P.: Chemistry of the 1991-1992 stratospheric winter: Threedimensional model simulations, J. Geophys. Res., 99, 81838195, 1994.

Liang, Q., Jaegle, L., Jaffe, D. A., Weiss-Penzias, P., Heckman, A., and Snow, J. A.: Long-range transport of Asian pollution to the northeast Pacific: Seasonal variations and transport pathways of carbon monoxide, J. Geophys. Res., 109, D23S07, doi:10.1029/2003JD004402, 2004.

Madronich, S. and Flocke, S.: The role of solar radiation in atmospheric chemistry, Handbook of Environmental Chemistry, edited by: Boule, P., Springer-Verlag, Heidelberg, 1-26, 1999.

Marchand, M., Godin, S., Hauchecorne, A., F. Lefèvre, Bekki, S., and Chipperfield, M.: Influence of polar ozone loss on northern midlatitude regions estimated by a high-resolution chemistry transport model during winter 1999/2000, J. Geophys. Res, 108, 8326, doi:10.1029/2001JD000906, 2003.

Moreau, G., Robert, C., Catoire, V., Chartier, M., Camy-Peret, C., Huret, N., Pirre, M., Pomathiod, L., and Chalumeau, G.: A multispecies in situ balloon-borne experiment with six tunable diode laser spectrometers, Appl. Opt., 44, 5972-5989, 2005.

Orsolini, Y. J.: Long-lived tracer patterns in the summer polar stratosphere, Geophys. Res. Lett., 28, 3855-3858, 2001.

Pan, L. L., Randel, W. J., Gary, B. L., Mahoney, M. J., and Hintsa, E. J.: Definitions and sharpness of the extratropical tropopause: A trace gas perspective, J. Geophys. Res., 109, D23103, doi:10.1029/2004JD004982, 2004.

Pierce, R. B., Al-Saadi, J. A., Fairlie, T. D., Olson, J. R., Eckman, R. S., Grose, W. L., Lingenfelser, G. S., and Russell III, J. M.: Large-scale stratospheric ozone photochemistry and transport during the POLARIS Campaign, J. Geophys. Res., 104, 26525-26545, doi:10.1029/1999JD900395, 1999.

Pirre, M., Pisso, I., Marecal, V., Catoire, V., Mebarki, Y., and Robert, C.: Intrusion of recent air in midlatitude stratosphere revealed by in situ tracer measurements and trajectory calculations, J. Geophys. Res., 113, D11302, doi:10.1029/2007JD009188, 2008.

Raatz, W. E. and Shaw, G. E.: Long-range tropospheric transport of pollution aerosols in the Alaskan Arctic, J. Clim. Appl. Meteorol., 23, 1052-1064, 1984.

Revercomb, H. E., Buijs, H., Howell, H. B., LaPorte, D. D., Smith, W. L., and Sromovsky, L. A: Radiometric calibration of IR Fourier transform spectrometers: solution to a problem with the High-resolution Interferometer Sounder, Appl. Opt., 27, 32103218, 1988.

Rinke, A., Dethloff, K., and Fortmann, M.: Regional climate effects of Arctic haze, Geophys. Res. Lett., 31, L16202, doi:10.1029/2004GL020318, 2004.
Roiger, A., Schlager, H., Schäfler, A., Huntrieser, H., Scheibe, M., Aufmhoff, H., Cooper, O. R., Sodemann, H., Stohl, A., Burkhart, J., Lazzara, M., Schiller, C., Law, K. S., and Arnold, F.: Insitu observation of Asian pollution transported into the Arctic lowermost stratosphere, Atmos. Chem. Phys., 11, 10975-10994, doi:10.5194/acp-11-10975-2011, 2011.

Sander, S. P., Ravishankara, A. R., Golden, D. M., Kolb, C. E., Kurylo, M. J., Molina, M. J., Moortgat, G. K., Finlayson-Pitts, B. J., Wine, P. H., and Huie, R. E.: Chemical Kinetics and Photochemical Data for Use in Atmospheric Studies Evaluation Number 15, JPL Publication, Jet Propulsion Laboratory, Pasadena CA, USA, 06-2, 2006.

Seinfeld, J. H. and Pandis, S. N.: Atmospheric chemistry and physics: from Air Pollution to Climate Change, chapter 7, Second edition, John Wiley \& Sons Ed, Inc., New York, 46-47, 2006.

Stohl, A., Wotawa, G., Seibert, P., and Kromp-Kolb, H.: Interpolation errors in wind fields as a function of spatial and temporal resolution and their impact on different types of kinematic trajectories, J. Appl. Meteor., 34, 2149-2165, 1995.

Stohl, A.: A 1-year Lagrangian "climatology" of airstreams in the Northern Hemisphere troposphere and lowermost stratosphere, J. Geophys. Res., 106, 7263-7279, 2001.

Stohl, A., Forster, C., Huntrieser, H., Mannstein, H., McMillan, W. W., Petzold, A., Schlager, H., and Weinzierl, B.: Aircraft measurements over Europe of an air pollution plume from Southeast Asia - aerosol and chemical characterization, Atmos. Chem. Phys., 7, 913-937, doi:10.5194/acp-7-913-2007, 2007.

Té, Y., Jeseck, P., Camy-Peyret, C., Payan, S., Perron, G., and Aubertin, G.: Balloonborne calibrated spectroradiometer for atmospheric nadir sounding, Appl. Opt., 41, 6431-6441, 2002.

Té, Y., Jeseck, P., Pépin, I., and Camy-Peyret, C.: A method to retrieve blackbody temperature errors in the two points radiometric calibration, Infrared Physics \& Technology, 52, 187-192, doi:10.1016/j.infrared.2009.07.003, 2009.

Thiéblemont, R., Huret, N., Orsolini, Y. J., Hauchecorne, A., and Drouin, M.-A.: Frozen-in anticyclones occurring in polar Northern Hemisphere during springtime: Characterization, occurrence and link with quasi-biennial oscillation, J. Geophys. Res., 116, D20110, doi:10.1029/2011JD016042, 2011.

Wernli, H. and Bourqui, M.: A Lagrangian "1-year climatology" of (deep) cross-tropopause exchange in the extratropical Northern Hemisphere, J. Geophys. Res., 107, 4021, doi:10.1029/2001JD000812, 2002.

World Meteorological Organization (WMO): Meteorology: A threedimensional science, WMO Bull., 4, 134-138, Geneva, Switzerland, 1957.

Wotawa, G. and Trainer, M.: The Infuence of Canadian Forest Fires on Pollutant Concentrations in the United States, Science, 288, 324 pp., doi:10.1126/science.288.5464.324, 2000. 